\title{
Working
}

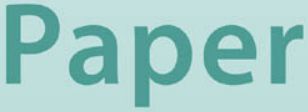




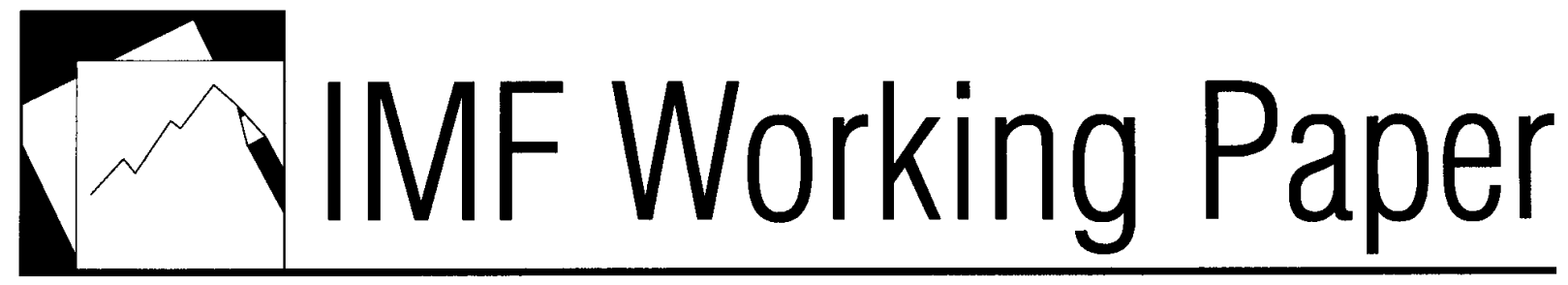

$\mathrm{H}$

Commitment in Weak(er) Institutional Environments

Sophia Gollwitzer and Marc Quintyn 


\title{
IMF Working Paper
}

IMF Institute

\section{The Effectiveness of Macroeconomic Commitment in Weak(er) Institutional Environments}

\author{
Prepared by Sophia Gollwitzer and Marc Quintyn ${ }^{1}$
}

Authorized for distribution by Marc Quintyn

August 2010

\begin{abstract}

\section{This Working Paper should not be reported as representing the views of the IMF.} The views expressed in this Working Paper are those of the author(s) and do not necessarily represent those of the IMF or IMF policy. Working Papers describe research in progress by the author(s) and are published to elicit comments and to further debate.
\end{abstract}

This paper analyzes the institutional conditions affecting the establishment and effectiveness of independent central banks and of budgetary institutions. It draws on the recent theory developed by North, Wallis and Weingast on the transition from a closed and fragile state to an open economic and political environment. The paper presents a composite indicator allowing for the identification of a country's position along this transition path. The findings suggest that (i) while the establishment of autonomous central banks seems to be relatively independent from the broader institutional framework, sound budgetary institutions tend to be established in countries with higher levels of rule of law for the elites, and (ii) while central bank independence is effective in reducing inflation irrespective of a country's position along the transition path, budget institutions seem to be most effective as a disciplining device in weak institutional environments.

JEL Classification Numbers:E52, E58, E62, H61, O23, P16, P48

Keywords: Macroeconomic Commitment Institutions, Political-Economic Institutions, Central Bank Independence, Budgetary Institutions, Doorstep Conditions

Author’s E-Mail Address: Sophia.gollwitzer@graduateinstitute.ch, and mquintyn@imf.org

\footnotetext{
${ }^{1}$ This paper was written while Sophia Gollwitzer was visiting scholar at the IMF Institute. The authors would like to thank Rene Aubourg, Camelia Minoiu, Ugo Panizza, Pierre-Louis Vezina, John Joseph Wallis, Charles Wyplosz and participants at an IMF Institute seminar for helpful comments and suggestions. The authors remain solely responsible for any remaining mistakes and shortcomings.
} 
I. Introduction

II. Literature

A. Central Bank Independence

B. Budget Institutions

C. The Institutional Framework in Developing Countries

III. New Contribution and Theory

A. Doorsteps and the Establishment of MCI

B. Doorsteps and the Effectiveness of MCI.

IV. A Composite Indicator of Doorstep Conditions .12

A. First Doorstep: The Rule of Law for Elites.

B. Second Doorstep: Perpetual Forms of Organizations

C. Third Doorstep: Political Control of the Military

D. Aggregation of the Index

V. Empirical Analysis. $\underline{18}$

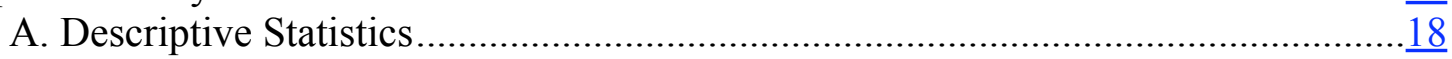

B. Econometric Analysis $\underline{19}$

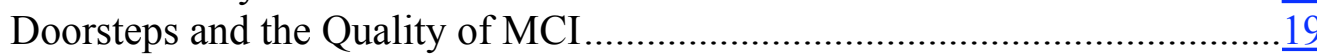

Doorsteps and the Impact of MCI...........................................................

Caveats and Robustness Checks

VI. Conclusion .$\underline{25}$

Reference

\section{Figures}

1: Country Rankings and Doorsteps: D1 .33

2: Country Rankings Under Doorsteps: D2 $\frac{33}{34}$

3: Country Rankings Under Doorsteps: D3

4: Overall Doorsteps and CBI

5: $\mathrm{D} 1$ and $\mathrm{CBI}$ .34

6: $\mathrm{D} 2$ and $\mathrm{CBI}$

7: $\mathrm{D} 3$ and $\mathrm{CBI}$ .35

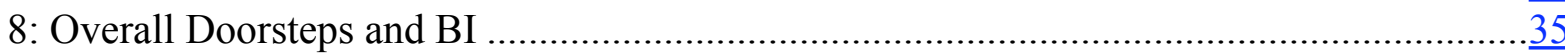

9: D1 and BI

10: $\mathrm{D} 2$ and $\mathrm{BI}$ .$\frac{36}{36}$

11: D3 and BI $\frac{36}{36}$

12: The Effectiveness of CBI for Low D1 (a through e) ....................................................

13.a: Marginal Effect of BI on PED (varying D1)....

13.b: Marginal Effect of BI on PED (varying D1D2)

13.c: Marginal Effect of BI on PED (varying D1D2D3)

14: The Effectiveness of BI for Low D1 (a through e) 


\section{TABLES}

1: Components of the First Doorstep. .13

2: Components of the Second Doorstep...

3: Components of the Third Doorstep

4: Spearman Rank Correlations among Sub-Indices

5: Average Index Values per Income Group

6: Doorsteps and CBI

7: Doorsteps and the Budget Index

8: Doorsteps and the impact of CBI.

9: Split Samples-The Impact of CBI on Inflation with low D1

10: Split Samples-The Impact of CBI on Inflation with High D1

11: Doorstep and the Impact of BI.

12: Interactions between Doorsteps and Budget Index

13: Split Samples-The Impact of BI on PED with Low D

\section{Boxes}

1: NWW's Limited-and Open-Access Orders and the Transition .10

2: The Performance of Mauritius, Tanzania, and Chad under the Doorsteps

\section{Appendix Tables}

I: Databases Used for the Construction of the Doorsteps Index

II: Arnone (2007) CBI Index Scores Updated for 2009

III: Dabla Norris et al. (2010) BI Index Scores

IV: Description of Variables 


\section{INTRODUCTION}

"The same institution produces different results depending on the context." (North, 1990: p. 54)

Central bank independence (CBI) and sound budgetary institutions (BI) have been hailed as essential macroeconomic commitment institutions (MCI) to address the well-known issue of time-inconsistency in macroeconomic policymaking. Empirical evidence for advanced countries broadly supports this view: CBI seems to contribute to achieving lower levels of inflation, while sound BI lead to lower public debt and deficit levels.

While originating from economies characterized by mature democratic systems and high quality institutions where independence, accountability and transparency underpin their operation effectively, MCI have also been widely promoted in low and middle-income countries (LIC and MIC, respectively), which typically have weak(er) institutional frameworks. Over the past two decades, they have been an integral part of IMF and World Bank program conditionality. However, studies on the impact of these institutions in a LIC- setting are scarce, and the few that exist show mixed results. Cukierman et al. (1992), De Haan and Sierman (1996), and Crowe and Meade (2008) show that CBI is not necessarily associated with lower inflation in LICs. The literature on budget institutions in LICs is still nascent and so far no study has compared the effectiveness of budget institutions in advanced countries with LICs.

The question thus arises, under which conditions these institutions can be effective, or more generally, what their interaction is with a country's broader institutional framework. For CBI, Keefer and Stasavage (2001), Eijffinger and Stadhouders (2003), and Acemoglu et al. (2008) suggest that its effectiveness is determined by certain characteristics of the broader framework, such as the rule of law and the presence of institutional constraints (checks and balances). To our knowledge, no comparable research has been undertaken for the effectiveness of BI.

This paper contributes to our understanding of the interaction between a country's broader institutional framework and the impact of MCI in two ways. First, we include both types of $\mathrm{MCI}-\mathrm{CBI}$ and $\mathrm{BI}-$ in our analysis, a comparison that that has not been undertaken hitherto. This allows us to identify similarities and differences in the interaction between the two MCI and the institutional framework. Secondly, our modeling of the broader institutional framework and its interaction with MCI is inspired by recent work by North, Wallis and Weingast (henceforth NWW) on the transition from a closed and fragile state to an open economic and political environment. NWW argue that in order to reach the doorstep from which transition towards an open political and economic order is possible, countries have to meet a number of conditions. These socalled doorstep conditions allow us to better differentiate the different stages of what is typically summarized as "weak(er) institutional environments" as they provide us with some evolutionary perspective. 
This paper explores two separate, yet interconnected questions. First we analyze which variables of the economic and institutional environment (represented by the doorstep conditions) are associated with the introduction and the quality of MCI in a set of LICs and MICs. Second, we explore the effectiveness of MCI in light of a country's performance under the doorstep conditions. To answer both questions, we construct a composite indicator which allows us to identify a country's position along the transition path according to the characteristics of the doorstep conditions.

Several interesting findings emerge from this research. First, while the decision to establish an autonomous central bank seems to be relatively independent of the broader institutional framework, sound budgetary institutions are more likely to be established in countries with a higher degree of rule of law for the elites (doorstep 1). Second, whereas a higher rule of law by itself seems to contribute to macroeconomic stability by reducing inflation, $\mathrm{CBI}$ is found to be effective in reducing inflation irrespective of the broader institutional framework. In other words, rule of law for the elites and CBI each play an independent role in containing inflation. Interestingly enough, our findings for BI are quite different. Here we observe that, the further countries progress along doorstep 1 and doorstep 2 (the entrenchment of perpetual organizations) the smaller the impact of BI on fiscal outcomes becomes. Put differently, BI seem to be most effective as a disciplining device in the weakest institutional environments, but once other disciplining devices in the broader institutional framework are in place, the marginal impact of BI decreases. Thus, while CBI and the quality of the broader institutional framework are complementary, predetermined fiscal rules and procedures and the overall institutional quality act as substitutes.

The observed differences are not surprising, given the design and mode of operation of the two MCI. CBI involves self-disciplining through delegation of an entire policy domain to an independent agency. CBI, as an institution, delivers its own contribution to containing inflation, in addition to any contribution coming from the institutional framework. ${ }^{2}$ Moreover, the costs to the government of interfering with or breaking the contract are relatively high, even in weak institutional environments. ${ }^{3} \mathrm{BI}$ on the other hand is a self-disciplining device for the management of a policy domain that is at the heart of politics. Our empirical results suggest that in the weakest of institutional environments, if governments succeed in imposing this self-disciplining device, it tends to improve the budgetary outcomes. However, once other elements of the broader institutional framework, which also impose self-discipline on the political class evolve, they can achieve the same effects as BI.

This paper is structured as follows: Section II reviews the relevant literature on CBI and $\mathrm{BI}$ and summarizes the theory of NWW. The subsequent section describes our contribution to the literature. Section IV presents our composite institutional indicator for

\footnotetext{
${ }^{2}$ See Maxfield (1997) for the political economy advantages of CBI in developing countries.

${ }^{3}$ See McCallum (1995) for a discussion of these costs.
} 
a sample of 77 low- and middle-income countries. Section V turns to the empirical analysis. Section VI concludes.

\section{LITERATURE}

This paper is related to various strands in the literature. First of all, there is an entire body of literature on macroeconomic commitment institutions, i.e. institutions pledging policymakers to pre-established rules and procedures in monetary and fiscal policymaking, in order to overcome the issue of time-inconsistency. Secondly, our paper is related to the institutional economics school. Finally, it adds to the nascent literature on the interplay between the effectiveness of commitment and constraints and the institutional framework.

\section{A. Central Bank Independence}

Ever since the seminal paper by Rogoff (1985) suggesting that the delegation of monetary policy from the government to an independent and inflation-averse central banker could solve the Kydland and Prescott (1977) and Barro and Gordon (1983) timeinconsistency problem, CBI has been hailed as best practice in monetary policy-making. The success of CBI in containing inflation in advanced countries has stimulated similar policy reforms in other country groupings in the past two decades, often under the aegis of the international financial institutions. ${ }^{4}$

To measure the effectiveness of CBI a substantial literature has developed that quantifies CBI. Following earlier attempts by Bade and Parkin (1982) and Alesina (1988), Grilli, Masciandaro and Tabellini (1991) construct an index consisting of two measures of legal central bank independence: political autonomy and economic autonomy. Further refinements were introduced by Cukierman (1992) and Cukierman, Webb and Neyapti (1992). More recently, other scholars have proposed amendments or refinements to these now classical indices. ${ }^{5}$

Several scholars have identified a significant, inverse relationship between measures of legal CBI and inflation in industrial countries. ${ }^{6}$ However, the evidence of such a relationship is much weaker for developing countries. ${ }^{7}$ Attempts to address these puzzling

\footnotetext{
${ }^{4}$ See for instance Arnone et al. (2007) and Crowe and Meade (2008) who find that in a broad range of developed and developing countries central banks have become far more independent over the past 20 years.

${ }^{5}$ Lybek (1999) adds publication and reporting and financial independence. Jácome (2001) includes lender-of-last resort mechanisms.

${ }^{6}$ See, for example, Alesina (1988); Grilli et al. (1991); Alesina and Summers (1993); Eijffinger et al. (1998).

${ }^{7}$ See Cukierman et al. (1992) and De Haan and Sierman (1996).
} 
results fall into two schools. ${ }^{8}$ One school proposes modifications to the classical CBIindex, arguing that indices developed for advanced economies are not necessarily applicable to the LIC or MIC context. Cukierman (1992) and Cukierman et al. (1992) argue that legal CBI is less relevant in developing countries where legal enforcement mechanisms are much weaker than in developed countries. Consequently proxies of the actual independence of the central bank should be analyzed. ${ }^{9}$ The evidence on the effect of these measures of CBI on inflation is mixed..$^{10}$ Gutierrez (2003) ascertains that in Latin America, constitutional entrenchment of CBI is associated with lower inflation, and should therefore be part of the index. Gollwitzer (2010) develops an Africa-specific measure of CBI by adjusting several of the conventional CBI criteria to a LIC context and finds a significant negative correlation between inflation and CBI.

The other school takes a broader view by explicitly testing the impact of the institutional environment on the effectiveness of CBI. Three contributions are closely related to our paper. Keefer and Stasavage (2001) argue that CBI is only associated with lower inflation in the presence of checks and balances on the executive. They argue that political institutions are crucial to the sustainability and effectiveness of decision making by independent agencies." Eijffinger and Stadhouders (2003) show that for a sample of developed and developing countries the effectiveness of legal CBI is determined by the rule of law. ${ }^{11}$ Moreover, for transition economies they find that inflation and CBI are not related during early phases of economic liberalization but that, once sufficient levels of liberalization have been achieved, CBI contributes significantly to achieving price stability. ${ }^{12}$ Acemoglu, Johnson, Querubim, and Robinson (2008) investigate the interplay between institutional constraints and CBI as typical policy reform. They find that reforms enhancing CBI do not reduce inflation levels when institutional constraints are either very low or very high. At high levels there is little room for improvement and at low levels reforms can easily be undermined. Moreover, for very low levels of constraints, reforms improving CBI may actually worsen fiscal performance as policymakers switch to this instrument to attain the goal that was formerly targeted by inflation, the so-called "seesaw effect". Thus, reforms seem to be most effective in countries with "intermediate levels of constraints."

\footnotetext{
${ }^{8}$ For a more detailed review of this literature, see Quintyn (2008).

${ }^{9}$ They suggest the turnover rate of central bank governors and political vulnerability (the fraction of times that a political transition is followed within six months by a replacement of the central bank governor) as indicators for actual CBI.

${ }^{10}$ Cukierman (1992), Crowe and Meade (2008) and Jacome and Vazquez (2008) find a negative relationship between inflation and the turnover rates for samples of developing countries, a result that is not corroborated by Lybek (1999) for former Soviet republics. Sturm and De Haan (2001) find that the turnover only becomes significant when high inflation countries are included. Cukierman et al. (1993) find that the effect of political vulnerability on inflation is similar to that of the turnover rate.

${ }^{11}$ The rule of law is accounted for by variables measuring the repudiation of contracts by the government, bureaucratic quality, and the overall rule of law.

${ }^{12}$ Note however that their model is mis-specified as they do not include the interacted variables separately when including an interaction term.
} 


\section{B. Budget Institutions}

The literature analyzing the quality and impact of $\mathrm{BI}$ is younger than the field of $\mathrm{CBI}$ and dates back to the seminal contributions by von Hagen (1992) and von Hagen and Harden (1994) who argued that a centralized budget process promotes fiscal discipline. They construct an index of the level of centralization in the budget process consisting of three sub-indices (the structure of negotiations at the government stage, the parliamentary stage of the budget, and the flexibility of implementing the budget). Studying fiscal rules in European countries, Hallerberg and von Hagen (1999) and Hallerberg, Strauch and von Hagen (2004) argue that a centralized budget process may not be optimal for all countries. In particular, they find that countries with coalition governments might not find it feasible to centralize the budget process. They identify two distinct institutional approaches to overcome the deficit bias in public budgeting. Under the delegation approach all budgetary power is centralized in the ministry of finance. The contract approach, on the other hand, is based on pre-established budgetary targets and rules.

Building on the findings by von Hagen et al. several studies have constructed indices on the quality of BI and analyzed their impact on fiscal outcomes. Alesina, Hausman, Hommes and Stein (1999) assess BI in Latin America according to the entrenchment of fiscal constraints, budget transparency, and hierarchical versus collegial elements. They find that fiscal constraints and hierarchical and transparent procedures enhance fiscal discipline. Fabrizio and Mody (2006) develop an index on the quality of BI capturing checks and balances through hierarchical rules and collegiality. They conclude that for ten new and potential EU members the quality of budgetary institutions mattered strongly in determining fiscal outcomes between 1997 and 2003. Mulas-Granados et al. (2009) confirm that budgetary institutions have a significant and positive impact on fiscal performance in the new EU members.

As is the case with $\mathrm{CBI}$ indices, indicators designed to measure the quality of $\mathrm{BI}$ in advanced countries may not be suitable for measuring the quality of budget institutions in LICs. Indeed, during the budget process, LICs face a number of challenges that are not encountered by more developed countries and that could make transplantation of best practices from OECD countries ineffective. ${ }^{13}$ Dabla-Norris et al. (2010) build an index specifically designed to capture the particularities of the budget process in LICs and emerging countries. Their index, which focuses on the expenditure side of the budget, measures the level of centralization (top-down procedures), rules and controls, sustainability and credibility, comprehensiveness, and transparency at each of the three budget phases. ${ }^{14}$ It incorporates a few aspects of the greater institutional framework, such as the role of the legislature, and the public's ability to monitor the budget process. For their sample of 44 LICs and 28 MICs, the authors show that on average LICs have weaker budget institutions than MICs. They find that stronger budget institutions are

\footnotetext{
${ }^{13}$ See Dabla-Norris et al. (2010) for a detailed survey of the problems related to the budget process in LICs.

${ }^{14}$ The three budget phases are budgetary planning, legislative approval, and implementation.
} 
associated with higher primary fiscal balances and lower public external debt. Better budget institutions also seem to promote less pro-cyclical fiscal policies.

\section{The Institutional Framework in Developing Countries}

To model the institutional context within which we analyze the impact of MCI, we rely on recent work by North, Wallis, and Weingast (2006 and 2009). They develop an institutional explanation for the divergence in economic and political development across the world, based upon political, economic and sociological theories. ${ }^{15}$ Starting from the premise that the prime objective of any type of social order is to contain violence in society, they argue that there are broadly two social orders in the world today: an open access order and a limited access order. Both orders are able to solve the problem of containing violence but in very different ways. Most countries are characterized by limited access, which is why NWW call this social order the natural state. While the natural state has been in existence during the last 10,000 years, open access societies have only emerged in the last 300 years. Box 1 explains in more detail the differences between, and dynamics of, these two types of social order.

One of the main contributions of NWW - and of relevance to our approach - is their theory on the transition from the natural state to the open access order. Transition from limited to open access is neither automatic nor irreversible and occurs in several steps. They show that in most of the pioneering cases, the transition was driven by institutions that were created, or measures that were taken, with other (mostly limited) objectives in mind - in other words, not with the intention of creating an "open access" society, because no one could imagine what such a society actually would entail. Close analysis of many of these multiple, unintentional steps allows the authors now with hindsight to present in a stylized way, a number of steps through which countries need to go in their transition from a natural state to an open access society.

The authors divide these "stylized steps" into three sets of doorstep conditions. Once a society has achieved most of these three doorstep conditions, it finds itself at the threshold of an open access society. These three doorstep conditions are the rule of law for the elites, existence of perpetually lived organizations, and consolidated political control of the military. While country examples show that some sequence needs to be respected, the three doorsteps also interact at various levels and, allowing for local circumstances, various configurations are possible.

The rule of law for elites requires the "establishment of a judicial system in which individuals with the appropriate standing have access to rules and procedures [...] whose decisions are binding and unbiased, at least with respect to elites" (NWW, 2009, p. 151). Perpetually lived organizations are defined as "perpetually lived forms of public and private elite organizations, including the state itself" (NWW, 2009, p.26). And finally,

\footnotetext{
${ }^{15}$ This work is based upon earlier individual and joint studies by the authors, but it also offers some sort of synthesis of the work of many other authors in this field, as NWW acknowledge.
} 
consolidated political control over the military requires "the existence of an organization with control over all the military resources of the country; that control over the various military assets is consolidated in that organization; and a set of credible conventions that determine how force is used against individuals and coalition members" (NWW, 2009, p. $153)$.

\section{Box 1: NWW's Limited-and Open-Access Orders and the Transition}

NWW define limited access orders as states which contain violence through rent creation from limiting entry to the economic and political system. This order is characterized by a de-facto non-democratic political system, few organizations which are mostly associated with the state, a small and centralized government, as well as a "predominance of social relationships organized along personal lines, including privileges, social hierarchies, laws that are enforced unequally, insecure property rights, and a pervasive sense that not all individuals are equal."

Contrary to limited access orders, open access orders sustain social stability not through rent creation but through political and economic competition. Typical for these societies are a "rich and vibrant" civil society with a plethora of organizations, a big decentralized government, as well as "widespread impersonal social relationships, governed by rule of law, secure property rights, fairness, and equality - all aspects of treating everyone the same," leading to sustained political and economic development. NWW's idea of the economy under open access is modeled along the Schumpeterian concept of creative destruction, where new market entries and inventions replace old products and services all the time.

Although both orders create social stability, stable economic growth and sustainable political development is most likely to occur under the open access order. Moreover, the same institutions will work differently under the two social orders. NWW argue that "the lesson that the same institution works differently under limited as opposed to open access applies with particular force to the transfer of democratic institutions into natural states". For example, elections will not necessarily lead to democracy in the natural state.

Transition from limited to open access is neither automatic nor irreversible and occurs in several steps. NWW show that societies first move from fragile to basic and subsequently to mature natural states. Under basic natural states, public and private sector organizations become institutionalized but are always "closely associated with the (private) individual identities of the elites who inhabit them". In the next stage, under mature natural states, "credible institutions evolve that provide organizations a measure of law". "As more complex organizations develop, both inside and outside the formal government, the distinction between public and private organizations begins to disappear." At the same time, governments begin to establish monopoly control over the military. Finally, the extension of impersonal relationships within and beyond the elites creates open access.

1/ based on NWW (2006) and (2009)

It is critically important, according to the authors, that the fulfillment of the doorstep conditions must take place within the logic of the natural state and, thus, with the consent of the elites. ${ }^{16}$ Moreover, transition to the open access society requires the creation and

\footnotetext{
${ }^{16}$ Note that, unlike Acemoglu and Robinson (2006), NWW do not consider the elites to be one homogeneous group. Instead, elites are defined as "members of the dominant coalition" containing specialists in military, political and economic activities (see 2009, p. 18). They can compete and fall apart. Furthermore, and again unlike Acemoglu and Robinson, NWW do not assume that the elites are giving up something during the transition between the two social orders. Rather, "elites transform their unique and personal privileges into impersonal rights shared equally among elites" (p. 25).
} 
extension of impersonal relationships both at the political and at the economic level: "Economic and political access are deeply connected. Political responsiveness in open access orders reflects shifts in economic interests. This in turn, leads political officials to provide a range of public goods and services that respond to economic opportunities" NWW, 2009, p. 145).

\section{NEW CONTRIBUTION AND THEORY}

This paper intends to analyze the effectiveness of both types of MCI in LICs and MICs by using an alternative approach to institutional development. We quantify the level of realization of NWW's doorstep conditions in an index and subsequently study the relationship between this measure of institutional transition and (i) the establishment of $\mathrm{CBI}$ and BI and (ii) their impact on macroeconomic outcomes. NWW's doorstep conditions are related to a plentitude of institutional structures governing political, economic, and social interaction and thus represent a comprehensive measurement of a country's level of overall institutional development.

\section{A. Doorsteps and the Establishment of MCI}

The first research question concerns the relationship between a country's position on the institutional transition path and the quality of its MCI. We expect that MCI can only be fully developed as a country approaches the completion of the three doorsteps which make impersonal commitments credible and enforceable. Adherence to the rule of law for the elites is the prerequisite for the government to impose binding rules on the executive. If the elite (which includes the executive) is not accountable to anyone, the government will not be really tempted to establish an independent central bank or introduce binding rules and procedures into the budget process as monetary and fiscal policies will continue to be biased by the executive's preferences.

Likewise, the concept of perpetual organizations should be entrenched to some extent in a society to enable the establishment of MCIs. By definition, an independent central bank exists beyond the life (or term of office) of the governor and the government. Similarly, the processes, rules and procedures governing the annual budget process can only be called an institution if they persist beyond the current fiscal year and beyond the legislative period of the current government.

Finally, full political control of all the military forces in the country would ensure that the executive cannot be forced into different institutional arrangements by armed powerful groups of society. A priori it is hard to say what the impact of the third doorstep on the decision to establish MCI will be, because there is such a wide range of potential ways in which the military, or military groups, can have an impact on the government. For instance, we would expect that in fragmented states with various military pressure groups outside the control of the executive MCI are less likely to be established. At the other extreme, it is theoretically possible that military dictators would favor some selfdiscipline in the form of MCI. 


\section{B. Doorsteps and the Effectiveness of MCI}

While the link between the doorstep conditions and the establishment of MCI can, in practice, be "weakened" or "undermined" by other factors such external pressure, we anticipate that the fulfillment of the doorstep conditions will have an important impact on the effectiveness of $\mathrm{CBI}$ and sound $\mathrm{BI}$. However, it is not a clear a priori if a better overall institutional framework would increase or decrease the effectiveness of MCI. On the one hand, numerous examples from around the world show that, if countries are not ready to embrace reforms imposed externally, the results will not be as anticipated because the elites will implement these measures formally but try to find compensation through other means (e.g. the seesaw effect identified in Acemoglu et al. 2008). This suggests that a better overall institutional framework should enhance the effectiveness of $\mathrm{CBI}$ in reducing inflation and of sound BI in lowering deficits. On the other hand, it could be argued that once a country has achieved a certain level of rule of law for the elites and introduced perpetual organizations, the marginal impact of MCI could diminish. The government has already established that it is capable and willing to commit. This would imply that better performance under the doorstep conditions would reduce the impact of MCI.

\section{A COMPOSITE INDICATOR OF DOORSTEP CONDITIONS}

We construct a composite index, consisting of three sub-indices, intended to reflect a country's performance under the three doorstep conditions. We attempt to capture as closely as possible the criteria that NWW identify as critical elements of the three conditions. For the selection of variables we rely on five different databases (Appendix I).$^{17}$ In addition, a number of (mostly binary) variables were constructed using publicly available information on political institutions, such as constitutions and other pillars of legislation. All variables are rescaled to range between zero and one, where one indicates best practice.

\section{A. First Doorstep: The Rule of Law for Elites}

NWW's first doorstep condition, the rule of law for the elites, stands for the definition of elite rights and privileges associated with certain members of society. As the typical example for the emergence of the rule of law for the elites, NWW refer to the development of English land law between 1100 and $1660 .{ }^{18}$ We identify three essential components of the rule of law: first, the existence of rules for the elite; second, the independence and the impartiality of the judicial system; and third, the elite's respect for

\footnotetext{
${ }^{17}$ The Institutional Profiles Database (de Crombrugghe et al. 2006 and 2009); Polity IV (Marshall and Jaggers, 2008); Economic Freedom of the World (Gwartney et al., 2009); Database on Political Institutions (Beck et al., 2002); and Armed Conflict Database (IISS, 2009).

${ }^{18}$ In 1100 , Henry I promised in his coronation oath that on the death of a tenant, his heirs could inherit the land after the payment of a relief. Over the next 500 years English land law evolved until in 1660 the Tenures Abolition Act manifested rule of law for elite land.
} 
and compliance with the decisions of the courts. Table 1 summarizes the categories and variables contained in the sub-index.

\section{B. Second Doorstep: Perpetual Forms of Organizations}

The second doorstep condition contains the concept that is the most difficult to quantify, namely the creation of perpetually lived organizations. The life of a perpetual organization is "defined by the identity of the organization rather than the identity of its members" (NWW, 2009, p. 152). This implies that a representative of this organization can credibly commit a successor to a promise made today. During the transition process, perpetually lived organizations have to be created both in the public and in the private sector. For this to be possible, three conditions have to be fulfilled: first, organizations must become legal persons in the eye of the law "capable of bearing rights and duties" and "independent of the identity of individual members at any given moment"; second,

Table 1: Components of the First Doorstep

\begin{tabular}{|c|c|c|c|}
\hline \multicolumn{4}{|l|}{ "DOORSTEP 1} \\
\hline CATEGORY & $\begin{array}{l}\text { VARIABLE } \\
\text { NAME }\end{array}$ & DATABASE & DESCRIPTION \\
\hline \multirow{4}{*}{$\begin{array}{l}\text { Existence of the rules for } \\
\text { the elite }\end{array}$} & XREG & Polity IV & Regulation of chief executive recruitment \\
\hline & XCONST & Polity IV & $\begin{array}{l}\text { Constraints on the executive (where } \\
\text { constraints are defined as institutionalized } \\
\text { limitations) }\end{array}$ \\
\hline & PARREG & Polity IV & $\begin{array}{l}\text { Existence and range of binding rules on } \\
\text { when, whether and how political } \\
\text { preferences are expressed }\end{array}$ \\
\hline & ICC & & $\begin{array}{l}\text { Dummy: } 1 \text { if ICC membership is enacted } \\
\text { (as measure of the immunity of members of } \\
\text { the government) }\end{array}$ \\
\hline \multirow[t]{3}{*}{$\begin{array}{l}\text { Independence and } \\
\text { impartiality of the judicial } \\
\text { system }\end{array}$} & $\begin{array}{l}\text { A3050 } \\
\text { Or } \\
2 \mathrm{~A}\end{array}$ & $\begin{array}{l}\text { IPD (2009) } \\
\text { EFW }\end{array}$ & $\begin{array}{l}\text { Independence of the justice system from the } \\
\text { government }\end{array}$ \\
\hline & $2 \mathrm{~B}$ & EFW & Impartiality of the courts \\
\hline & $2 \mathrm{E}$ & EFW & Integrity of the legal system \\
\hline \multirow{6}{*}{$\begin{array}{l}\text { Elite's respect for the } \\
\text { courts' decisions } 1 /\end{array}$} & $\mathrm{A} 604$ & IPD (2009) & Government's respect for contracts \\
\hline & A600 & IPD (2009) & Security of property rights \\
\hline & $\mathrm{A} 601$ & $\mathrm{IPD}(2009)$ & Security of contracts between private agents \\
\hline & \multicolumn{3}{|r|}{ 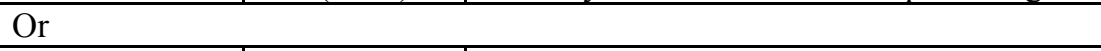 } \\
\hline & $2 \mathrm{C}$ & EFW & Protection of property rights \\
\hline & $2 \mathrm{~F}$ & FW & Legal enforcement of contracts \\
\hline
\end{tabular}

1/ This category is measured by different variables depending on whether or not IPD (2009) is available.

We quantify the second doorstep in two different categories. The first category assesses the stability and permanence of the political system, as a proxy for the perpetuity of the state. The second category evaluates the ease with which independent organizationsindependent from the state and recognized by the law — can be created. This serves as indication of a society's attitude towards organizations and of the legal role of organizations. Table 2 describes the components of the two categories. 
people have to understand and believe that these organization are perpetually lived; and third, the state has to be a perpetually lived organization as "a mortal state cannot credibly create a perpetual organization" (NWW, 2009), p. 152. NWW argue that in medieval Europe the investiture struggle and the resulting creation of the christus and fiscus laid the foundation for the emergence of perpetually lived organizations. ${ }^{19}$

Table 2: Components of the Second Doorstep

\begin{tabular}{|c|c|c|c|}
\hline \multicolumn{4}{|l|}{ DOORSTEP 2} \\
\hline CATEGORY & $\begin{array}{l}\text { VARIABLE } \\
\text { NAME }\end{array}$ & DATABASE & DESCRIPTION \\
\hline \multirow[t]{6}{*}{$\begin{array}{l}\text { Stability and } \\
\text { permanence of the } \\
\text { political system }\end{array}$} & A105 & IPD (2009) & $\begin{array}{l}\text { Stability of the political system (where stability } \\
\text { is measured in terms of the change in and } \\
\text { compliance with rules concerning the head of } \\
\text { state's accession to power) }\end{array}$ \\
\hline & A500 & IPD (2009) & $\begin{array}{l}\text { Dialogue structures headed by the political } \\
\text { authority to find a common interest among } \\
\text { stakeholders }\end{array}$ \\
\hline & Interregnum & Polity IV & $\begin{array}{l}\text { Number of Interregnum periods in Polity IV } \\
\text { between } 1995 \text { and } 2008 \text { accounting for the } \\
\text { periods of collapse of the political system and } \\
\text { divided by } 14\end{array}$ \\
\hline & Age of parties & DPI (2006) & Average age of political parties in 2009 \\
\hline & Finittrm & DPI (2006) & $\begin{array}{l}\text { Dummy: } 1 \text { if there is a constitutional limit on the } \\
\text { number of years an executive can serve }\end{array}$ \\
\hline & $\begin{array}{l}\text { Constitutional } \\
\text { stability }\end{array}$ & & $\begin{array}{l}\text { Number of changes in the constitution between } \\
1995 \text { and } 2009 \text { divided by } 15\end{array}$ \\
\hline \multirow[t]{10}{*}{$\begin{array}{l}\text { Ease of creating } \\
\text { organizations } 1 /\end{array}$} & A602 & IPD (2006) & $\begin{array}{l}\text { Form of contracts between private agents (oral } \\
\text { or written form; with or without mediation) }\end{array}$ \\
\hline & A504 & IPD (2006) & $\begin{array}{l}\text { Degree to which organizations are representative } \\
\text { of all stakeholders }\end{array}$ \\
\hline & B300 & IPD (2006) & $\begin{array}{l}\text { Administrative steps required for the creation of } \\
\text { an organization }\end{array}$ \\
\hline & $\mathrm{B} 700$ & IPD (2009) & $\begin{array}{l}\text { Ease of market entry for new firms in production } \\
\text { sector }\end{array}$ \\
\hline & D100 & IPD (2009) & Freedom of association \\
\hline & D101 & IPD (2009) & Pluralism and autonomy of trade unions \\
\hline & \multicolumn{3}{|r|}{ 政 } \\
\hline & 5C(ii) & EFW & Administrative requirements for businesses \\
\hline & 5C(iii) & EFW & Bureaucracy costs \\
\hline & $5 \mathrm{C}(\mathrm{iv})$ & EFW & Ease of starting a business \\
\hline
\end{tabular}

1/ This category is measured by two different sets of variables depending on the availability of IPD data.

\footnotetext{
${ }^{19}$ The corporate identity of the church in possession of the christus became the congregatio fidelium, the body of the faithful. Likewise the notion of the king came to consist of two bodies, the corporeal, mortal body, and the corporate, abstract body. As the congregatio fidelium and the corporate body of the king developed into perpetually lived organizations, a number of surrounding perpetual forms of organizations developed imposing constraints on and granting rights to the two bodies.
} 


\title{
C. Third Doorstep: Political Control of the Military
}

NWW argue that political control over the military is the hardest doorstep condition for a natural state to achieve. They provide an insightful, negative definition of the full meaning of this doorstep condition:

\begin{abstract}
"If active support of the military forces is necessary to hold or obtain control of civilian government institutions, then a society does not have political control of the military. If military officers serve as officers (...) in the civilian government, for example as legislators or executives, then a society does not have political control of the military. If the military as an organization enjoys ownership of significant economic assets that it can alienate or acquire without consent of the civilian authorities, then a society does not have political control of the military. Finally, the selection of the high military leadership must be under the control of the civilian authorities; armies who select their own leaders are not under political control." (NWW, 2009), p. 170
\end{abstract}

NWW explain that in Europe, political control of the military developed primarily out of military competition. In that context "separating the decisions of when to fight and how much to spend on fighting, from the direction of military activity was central." (NWW (2009) p. 171). We include three categories to measure performance under this doorstep condition. The first category evaluates political control of the legal armed forces. The second category accounts for military interference in political life. And the third category measures the level of armed violence in society as a de facto measure of political control over all military activity. The components of the categories are shown in Table 3 below.

\section{Aggregation of the Index}

The three indices are aggregated into one by applying equal weights. The categories are aggregated by simple averages into the three doorstep sub-indices, which are rescaled as ratios of their own averages. The final index is the average of the three sub-indices.

Figures 1 through 3 depict the countries ranked by their performance under the doorstep conditions. The index scores for the second doorstep display the least, and the scores for the first doorstep the most variation. Furthermore, the countries' relative performance differs across the three doorstep indices. ${ }^{20}$ By way of illustration, Box 2 discusses the scores obtained under the individual doorstep indices for three African countries by using information from reports published on these countries.

\footnotetext{
${ }^{20}$ While Chile, Poland, and Mauritius are the top three performers under the rule of law, the Philippines, Chile and Botswana perform best under perpetual forms of organizations, and Kazakhstan, Mozambique, and Argentina earn the highest scores under the political control of the military. At the other end of the spectrum, Cote d'Ivoire, Zimbabwe and Cameroon obtain the worst scores under the first doorstep, Gambia, Libya, and Chad occupy the three lowest positions under the second doorstep, and the Central African Republic, Paraguay and Uganda score worst under the third doorstep.
} 
Table 3: Components of the Third Doorstep

\begin{tabular}{|c|c|c|c|}
\hline \multicolumn{4}{|l|}{ DOORSTEP 3} \\
\hline CATEGORY & $\begin{array}{l}\text { VARIABLE } \\
\text { NAME }\end{array}$ & DATABASE & DESCRIPTION \\
\hline \multirow{3}{*}{$\begin{array}{l}\text { Political control } \\
\text { over the legal } \\
\text { armed forces }\end{array}$} & A201 & IPD (2009) & $\begin{array}{l}\text { Political authority's control over the legal } \\
\text { armed forces }\end{array}$ \\
\hline & MILITARY & DPI (2006) & $\begin{array}{l}\text { Dummy: } 1 \text { if the Chief Executive is a military } \\
\text { officer }\end{array}$ \\
\hline & $\begin{array}{l}\text { Parliamentary } \\
\text { oversight }\end{array}$ & & $\begin{array}{l}\text { Dummy: 1if parliament oversees military- and } \\
\text { defense-related operations }\end{array}$ \\
\hline \multirow{3}{*}{$\begin{array}{l}\text { Military } \\
\text { interference in } \\
\text { political life }\end{array}$} & A1002 & IPD (2006) & $\begin{array}{l}\text { De iure and de facto participation of the armed } \\
\text { forces in political life }\end{array}$ \\
\hline & $2 \mathrm{D}$ & EFW & $\begin{array}{l}\text { Measure of military interference in the rule of } \\
\text { law and in the political process }\end{array}$ \\
\hline & DEFMIN & DPI (2006) & $\begin{array}{l}\text { Dummy: } 1 \text { if the Defense Minister is a } \\
\text { military officer }\end{array}$ \\
\hline \multirow{6}{*}{$\begin{array}{l}\text { Level of armed } \\
\text { violence } 1 /\end{array}$} & A2000 & IPD (2009) & Security of persons and goods \\
\hline & A2001 & IPD (2009) & $\begin{array}{l}\text { Conflicts of ethnic, religious and regional } \\
\text { nature }\end{array}$ \\
\hline & A2002 & IPD (2009) & $\begin{array}{l}\text { Violent actions by underground political } \\
\text { organizations }\end{array}$ \\
\hline & \multicolumn{3}{|l|}{ Or } \\
\hline & $\begin{array}{l}\text { Internal armed } \\
\text { conflict and } \\
\text { internal terrorism }\end{array}$ & $\operatorname{ACD}(2009)$ & $\begin{array}{l}\text { Dummy: } 1 \text { in case of internal armed conflict } \\
\text { and internal terrorism }\end{array}$ \\
\hline & Annual fatalities & ACD (2009) & $\begin{array}{l}\text { Counts the military and civilian lives lost as a } \\
\text { direct result of an armed conflict in } 2008 \text { or } \\
2009 \text { (depending on the most recent update in } \\
\text { the database) with categorical dummies. }\end{array}$ \\
\hline
\end{tabular}

$1 /$ This category is measured by different variables depending on whether or not IPD (2009) is available.

\section{Box 2: The Performance of Mauritius, Tanzania, and Chad under the Doorsteps 1/}

Mauritius has been a stable democracy with free and fair elections and peaceful changes of government since independence in 1968. The country has a functioning market economy and has successfully adjusted to globalization. Mauritius' human rights record is positive and in 2009, Mauritius earned the highest overall score under the Ibrahim Index of African Governance. Overall, Mauritius corresponds to NWW's definition of a mature natural state on the verge to an open access society. Mauritius performs best under the doorstep conditions among the African countries included in our sample with an overall score of 1.36. Mauritius has a functioning legal system combining elements of British common law and French civil law. The separation of powers with an independent judiciary headed by the Supreme Court is guaranteed by the 1992 constitution and widely respected . Government actions are subject to frequent and in-depth parliamentary debates and the level of accountability of the executive is considered very high (reflected in a score of 1.54 under doorstep 1, i.e. the existence of the rule of law for the elites). Yet, the country only achieves a mediocre score for the independence and impartiality of the legal system (0.64). The 2010 report on Mauritius in the Bertelsmann Transformation Atlas expresses several concerns about the impartiality of the legal system: "there have been cases in which verdicts have seemed to be more opportunistic than founded in the law as such. On the one hand, procedural details impede objectivity and the rule of law 


\section{Box 2 - Continued}

when the social status of the person under trial is taken into account. On the other hand, the judiciary seems to be beyond technical and procedural control, as someone without protection can be held in custody without charge or trial".

The long democratic tradition and stability of the political system and of political and social institutions explains the relatively high (1.22) score under the second doorstep condition. Concerning, the third doorstep condition, the high overall score (1.32) can be explained in part by the fact that Mauritius does not have a standing army. All military, police, and security functions are carried out under the command of the Commissioner of Police in close cooperation with military advisers from the UK and India. The general level of security is very high and there has not been any noteworthy incidence of armed violence in the country's recent past.

Tanzania is an interesting example as our index scores represent averages of the mainland's and Zanzibar's performance under the doorstep conditions. If considered individually, it is very likely that the mainland would earn a considerably higher score than the semi-autonomous Zanzibar. On the mainland the government is chosen in generally free elections, whereas in Zanzibar electoral frauds and massive pre- and post-electoral violence have been reported. The country's progress towards democracy since Julius Nyerere stepped down as President in 1985 has been slow and the ruling CCM party has remained in power for over 40 years. Tanzania still ranks amongst the least developed countries in the world. Political participation and market competition are limited, the level of corruption is high and there are sporadic outbreaks of violence.

Although the judiciary is relatively independent, it is reported to be highly inefficient, with a workload far outweighing its capacity, and hardly able to conduct fair trials. The 2010 Transformation Atlas states that "the Prevention of Corruption Bureau's (PCB) record was poor. Of more than 10, 000 cases reported, only a paltry several hundred have been prosecuted (...) The government prosecuted almost no high-level corruption cases." The inefficiency of the judiciary and the high levels of corruption limit the enforceability of even basic property rights. The country's average performance under the first doorstep condition is low (1.02) and the score under independence and impartiality of the judicial system is only 0.41 . The Transformation Atlas reports that "independent political and civic groups - weak even by African standards — can form freely but are occasionally restricted by undemocratic interventions. [...]The landscape of interest groups is sparse. The trade unions are weak, and though they have managed to free themselves from their dependence on the former state party, they do not yet represent a fully independent force [...]. Self-organization in Tanzania has been limited to elitist and urban-based groupings out of touch with the broader society." The country's score under the second doorstep condition of 1.05 adequately reflects this situation. The picture for the third doorstep condition is similar. While the level of non-military armed violence is relatively low, there is a close link between the military and the political elite of the country. Almost the entire military leadership is integrated into the ruling party thus making it effectively impossible to talk about the political control of the military. This is reflected in the below-average score of 0.98 for this sub-index.

Chad, with an overall score of 0.66 , ranks lowest in our African sample and serves as an example of a fragile natural state. Since independence, the former French colony has experienced three decades of civil war and recurrent invasions by Libya until peace was restored in 1990. For the past 20 years the country has been run by an autocratic regime which has kept the regional government units weak, resulting in a general situation of chaos. Several rebellious factions cause frequent outbreaks of violence. Furthermore, the influx of roughly 300000 refugees from neighboring Sudan has not helped to improve the situation. The score for the first doorstep condition is 0.80 : although formally separate from the executive, the 


\section{Box 2 - end}

judiciary is entirely controlled by the government. The executive frequently intervenes in judicial decisions and the judges are known to be corrupt. This is reflected by the extremely low score $(0.11)$ for the category on the independence and impartiality of the judicial system. Furthermore, the courts' decisions are regularly ignored by the government. A prominent example is provided by the 2010 Transformation Atlas: "In January 2009, municipal state authorities ignored the magistrate's decision to suspend the demolitions of houses while further judiciary inquiries were being made. (...) Zene Bada, the mayor of N'djamena, declared that he was accountable to no one but the president." Members of the government and other members of the elite are reported to frequently enjoy impunity. The Bertelsmann report states that "judges acting independently face severe intimidation". Given the unstable political situation, the government's infringement of basic rights, such as the freedom of association, the high level of corruption, and the low level of security, the formation of perpetual forms of organizations is almost impossible. Organizations that do exist are closely linked to the present members of the ruling MPS. The Transformation Atlas writes:

"The topography of interest groups is meager. [...] According to a study published in 2003, there are five trade unions, around 2,000 registered organizations and 215 NGOs, of which 96 are operational. Since February 2008, many show signs of disintegration". The overall score under this doorstep condition is 0.69 . The score for Doorstep 3 is 0.49 . The legal armed forces do not possess the monopoly of violence in Chad and the executive is highly dependent upon the military, as the wave of desertion among the highest military ranks in 2005 has demonstrated.

1/ The information in this box is from the 2010 Transformation Atlas by the Bertelsmann Foundation.

\section{EMpirical ANALYSIS}

\section{A. Descriptive Statistics}

An analysis of the correlation among the three doorstep indices through Spearman rank correlations (Table 4) shows that the first doorstep condition is significantly and positively correlated with the other two doorstep conditions. There does not seem to be a significant correlation between perpetual organizations and the control of the military.

Table 5 presents differences (average score and standard deviations) in the fulfillment of doorstep conditions among three country income groups. Our final sample contains 27 LICs, 25 Lower MICs (LMIC), and 25 Upper MICs (UMIC). While the differences between LICs and LMICs are not that large (under some of the categories LICs even score slightly better than LMICs), the difference between the former two income groups and the UMICs is substantial. The latter score best in the rule of law sub-index and also score significantly better in the average of all three indicators, meaning that several of these countries are well-advanced in their transition to open access societies.

For the quantification of CBI and the quality of BI we rely on Arnone et al. (2007) and Dabbla Norris et al. (2010), respectively. We update the Arnone index using CB legislation as of 2009 (Appendix II). We find that LICs with an average overall score of 0.57 perform marginally worse than LMICs and UMICs with average scores of 0.60 and 0.62 respectively. The BI scores from Dabla-Norris et al. (2010) contain the most recent 
available data for each country (Appendix III). The quality of BI seems to be clearly related to a country's income level, with LICs at an average score of 1.98, LMICs at 2.07 and UMICs at 2.34.

Figures 4 to 11 depict the correlation between the overall doorsteps index and CBI and BI in scatter plots. While we cannot identify an obvious correlation between the doorsteps indices and CBI (apart from a slightly negative correlation between CBI and the second doorstep), the scatter plots suggest that the overall index is positively related to BI. This correlation seems to be driven by the clear and positive relationships between $\mathrm{D} 1$ and $\mathrm{BI}$ and between D2 and BI, suggesting that a country's performance under the rule of law for the elites and under perpetual organizations is linked to the quality of its BI.

\section{B. Econometric Analysis}

In the first part of the econometric analysis we ask if a country's performance under the doorstep conditions determines the quality of its MCI as measured by the $\mathrm{CBI}$ and $\mathrm{BI}$ indices. In the second part we analyze whether the fulfillment of the three doorstep conditions has an effect on the impact of MCI on inflation and public external debt. The analysis is conducted for averages over the period between 2003 and 2007. For the doorsteps indices and the indices describing the quality of the MCIs we only have one (the most recent) observation in time. Only countries for which we have at least two of the doorsteps sub-indices are included in the analysis.

\section{Doorsteps and the Quality of MCI}

To examine whether the decision to establish CBI is associated with a country's performance under the doorstep conditions, we run simple OLS regressions with robust estimates of the standard errors. We include the following explanatory variables: ${ }^{21} \mathrm{prg} f$ is a dummy for a Poverty Reduction and Growth Facility (by the IMF) in the country between 2000 and 2007 to capture donor-induced structural reforms; gdppc_2002, measuring the log of GDP per capita in 2002 accounts for differences in the initial economic situation; revenue represents average government revenue as percentage of GDP between 2003 and 2007 (this variable is meant to capture differences in the governments' incentives to obtain direct financing from the central bank); finally, we include a dummy for monetary unions $(\mathrm{mu})$, as we would expect member states of monetary unions to have better macroeconomic institutions, on average. We expect $C B I$ to be positively correlated with all four explanatory variables. We first run the regression without the doorsteps, and then we add the first doorstep $(d 1)$, the average of the first and second doorstep ( $d l d 2)$ and the average of the three doorsteps indices $(d l d 2 d 3)$.

We do not include the individual doorsteps indices separately in the regressions as we interpret NWW's theory as suggesting that what matters for the transition process is not a country's performance under any individual doorstep condition but the combined impact

${ }^{21}$ A description of all variables included in the regressions is included in Appendix A-IV. 
of, and interplay between, the three conditions in bringing a country to the doorstep of transition to an open access society. Although there is no unique sequence or path, it is clear from NWW (2009) that the establishment of a rule of law among the elites is the first (and perhaps most critical) condition to be fulfilled. The rule of law of the elites can be strengthened and extended through the creation of perpetual forms of organizations which facilitate the creation of impersonal relationships. The political control of the military, NWW argue, is extremely hard to achieve and is typically established considerably later than the other two doorstep conditions. By separately including the first doorstep, the average of the first and second doorstep, and the average of the three conditions, we try to identify which part of this process is the most relevant for the establishment and effectiveness of MCI. ${ }^{22}$

The most important result from this first set of regressions (Table 6) is that the general institutional framework does not seem to affect the decision to establish independent central banks. The associated coefficients for the doorstep indices are clearly insignificant and even have the wrong sign. The CBI index is significantly correlated only with GDP per capita and $m u$. Prgf is positive and only marginally insignificant suggesting that CBI tends to be implemented as part of IMF programs. Surprisingly, the revenue coefficient is negative and insignificant. The results suggest that $\mathrm{CBI}$ is more prevalent in richer countries as well as in monetary unions and tends to be implemented irrespective of the countries' position vis-à-vis the doorsteps. ${ }^{23}$

Table 7 presents the results of a similar regression for budget institutions. The independent variable is now the budget index (we use the index aggregated across stages, budget_stage). As explanatory variables we include prgf, gdppc_2002, and $m u$. Furthermore, we include a dummy for oil-exporting countries (oil). We expect the budget index to increase with prgf, gdppc_2002, and oil. The effect of membership in a monetary union is unclear. Convergence criteria within monetary unions could promote fiscal discipline and the introduction of improvements in budget institutions. Alternatively, the seesaw effect identified by Acemoglu, Johnson, Querubim and Robinson (2008) could result in a negative correlation between budgetary quality and membership in a monetary union.

GDP per capita and the oil dummy have a significant coefficient. Adding the first doorstep also greatly improves the explanatory power of the model. Unlike for CBI, the first doorstep is positively related to the quality of budget institutions at a significant level. Thus, countries with stronger rule of law for the elites seem to have better budget institutions. The other doorsteps indices have positive but insignificant coefficients. ${ }^{24}$

\footnotetext{
${ }^{22}$ As for some countries we do not have observations for all three doorsteps, we lose several observations under the specification including $d l d 2 d 3$. We therefore also run the regressions with a different measure (d_all) which is the average of the available doorsteps indicators (at least two). We exclude Zimbabwe from all regressions.

${ }^{23}$ The results do not change if we add the three doorsteps indices separately: none of the associated coefficients is significant and they are all negative.

${ }^{24}$ When including the doorsteps indices separately, only the first index is significant, confirming our above
}

(continued...) 
GDP per capita and the oil dummy become insignificant when the first doorstep is added, while the coefficient of $m u$ becomes significant when $d 1$ and $d 1 d 2$ are included. The negative sign in front of $m u$ provides some evidence for the seesaw effect, suggesting that tight monetary rules at the level of the union may actually worsen the quality of the national fiscal institutions. Again, the coefficient associated with $\operatorname{prgf}$ is only marginally insignificant. Overall, these findings validate our theory that a country's decision to establish sound budget institutions is related to the prevailing level of rule of law for the elites and that a minimum level of rule of law is required for this decision. ${ }^{25}$

\section{Doorsteps and the Impact of MCI}

Next, we turn to the impact of MCI on monetary and fiscal outcomes in light of the doorstep conditions. For CBI, the dependent variable is the average transformed inflation between 2003 and 2007, defined as the tax rate on reserve money (inflation). ${ }^{26}$ Apart from CBI, we include gdppc_2002, average growth between 2003 and 2007 (growth), mu, oil, as well as the following explanatory variables: the initial public external debt as ratio to GDP (ped_2002) to account for differences in initial fiscal performance; ${ }^{27}$ umi, a dummy for upper-middle-income countries as we expect this group to have lower inflation, and trade, which is defined as the product of annual growth in net barter terms of trade and the degree of openness of the economy and thus captures differences in the terms of trade and their importance to a country's economy. We expect inflation to decrease with $C B I$, gdppc_2002,ped_2002, mu, and umi, and to increase with growth. Oil and trade should increase the volatility of inflation but the anticipated sign of their impact on average inflation is not clear.

The CBI index has a significant and negative impact on inflation even before the doorsteps indices are added (Table 8). Initial GDP per capita and membership in a monetary union also have a significant and negative effect. Trade has a significant and positive coefficient. When adding the doorsteps indicators, only the first doorstep has a significant coefficient but - as expected — all four coefficients have a negative sign. In countries with a higher rule of law for the elites inflation tends to be lower than in countries with the same level of CBI but lower rule of law for the elites. When adding the first doorstep, the effect of gddppc_2002 becomes insignificant and the coefficient associated with CBI increases in size and significance (for the reduced sample). None of the interacted terms between the doorsteps indices and CBI are significant and including

findings. These results are available from the authors upon request.

${ }^{25}$ When including $\mathrm{d} 1, \mathrm{~d} 2$, and $\mathrm{d} 3$ separately in the regression, the overall results do not change. Only $\mathrm{d} 1$ has a significant coefficient. These results are available upon request.

${ }^{26}$ The tax rate on reserve money is defined as: $\frac{\pi_{i}}{\left(1+\pi_{i}\right)}$, where $\pi_{i}$ is the annual CPI inflation rate ranging

between 0 and one.

${ }^{27}$ It would certainly be better to include overall public debt. However, we do not have data on domestic debt for several of the countries included in our sample. 
the three individual doorsteps separately confirms our finding that only the first doorstep is significantly correlated with inflation. ${ }^{28}$

Given the strong impact of the rule of law for the elites on inflation and the increase in the size and significance of the coefficient associated with CBI following the introduction of the first doorstep into the regression, we test if the effectiveness of $\mathrm{CBI}$ in reducing inflation in countries with a weak rule of law differs from the effectiveness of CBI in countries with a high rule of law by splitting our sample into two sub-samples ( $d 1$ smaller or equal to 1 versus larger than 1). The results are presented in Tables 9 and 10. Although the coefficient of CBI is slightly lower for the sample with high $d 1$, the overall effectiveness of $\mathrm{CBI}$ in reducing inflation seems to be independent of the broader institutional framework. Figures $12 \mathrm{a}$ through $12 \mathrm{j}$ show the correlation of CBI and inflation conditional upon the other explanatory variables included in the regression for both sub-samples and for all of the regressions. The correlation is consistently negative across both samples. These results contrast with the findings by Keefer and Stasavage (2001), Eijffinger and Stadhouders (2004), or Acemoglu et al. (2009), who suggest that $\mathrm{CBI}$ is more effective in countries with more advanced institutional environments. One possible explanation for the differing results could be the time period under consideration. The three above-mentioned studies include data only up to the mid-1990s, while our analysis contains averages for the period 2003 - 2007. Over the past 15 years, a marked development in economic policy was the disappearance of fiscal dominance in a great number of LICs. As CBI can only effectively work in the absence of fiscal dominance, the overall effectiveness of CBI should have increased significantly since the late 1990s.

To analyze the impact of BI on fiscal outcomes against the background of a country's position under the doorsteps we use the same specification as Dabla-Norris et al (2010). As dependent variable we choose the average public external debt-to-GDP-ratio between 2003 and 2007..$^{29}$ Apart from the budget index, gdppc_2002, growth, ped_2002, oil, and trade, we include a dummy for reaching the Heavily Indebted Poor Countries Initiative completion point before 2007 (HIPC). We expect the external debt to decrease with the budget index, gdppc_2002, oil, trade, and HIPC and to increase with the initial debt level. The anticipated impact of growth is ambiguous as higher growth may lead to a lower debt due to the improved economic environment or to higher debt if expected continued future growth encourages a government to borrow against the future. We then add our doorsteps indices.

External debt is significantly and negatively correlated with the budget index even before we control for the doorsteps (table 9). We also find that initial debt is associated with higher contemporary debt, and that initial GDP per capita and the oil dummy seem to reduce external debt. All doorstep-indicators are strongly and negatively correlated with external debt. ${ }^{30}$ Interestingly, the impact of the budget index decreases in size and

\footnotetext{
${ }^{28}$ These results are available upon request.

${ }^{29}$ We exclude Burundi and DRC which have particularly high ratios of external debt to GDP.

${ }^{30}$ When adding the three doorstep sub-indices separately, only the first doorstep condition is significant
} (continued...) 
significance when we add the doorsteps to our regression. ${ }^{31}$ This result could indicate that the marginal impact of $\mathrm{BI}$ on public debt decreases as a country moves further along the transition process. But it may also be due to high correlation between the variables, as indeed we have shown that the quality of budget institutions is affected by a country's performance under the first doorstep condition.

To further test this relationship we add an interaction term of the budget index with the doorsteps (Table 13). The coefficients of the interaction term between budget_stage and $d 1$, and $d 1 d 2$ are highly significant and so are the coefficients of the two individual variables. The signs of the interaction terms are positive. Figures 13a through $13 \mathrm{c}$ show the marginal effect of budget_stage on public external debt for varying levels of the doorsteps indices. For low levels of $d 1$ and $d 1 d 2$ the marginal effect of BI on debt is negative. For higher levels of $d 1$ and $d 1 d 2$, however, the marginal impact of BI becomes insignificant and at very high levels of $d l$ even positive. We cannot detect a significant marginal impact of BI (at the 90 percent confidence level) when controlling for variations in $d 1 d 2 d 3$. This result strengthens our earlier assumption that the better a country performs under the first two doorstep conditions, the lower will be the marginal disciplining effect of good budget institutions on debt.

To investigate this "substitution effect" between budget institutions and the overall institutional quality in greater detail, we split our sample into countries with better and worse performance under the doorsteps. We apply two possible criteria for the construction of the sub-samples: performance under $d 1$ and performance under $d 1 d 2$. The results with both methods are similar but since the contrast between the two samples is more extreme for the split across $d 1$, we chose to report these results in Tables 14 and 15 and figures $14 \mathrm{a}-\mathrm{j}$. Conditional upon the explanatory variables included in the regressions of Table 9, budget_stage and ped are strongly and negatively correlated in countries with low levels of the rule of law. Yet, in countries with above-average levels of rule of law, the correlation between $\mathrm{BI}$ and debt is close to zero and under some specifications even positive. If countries have reached a certain level of overall institutional quality the marginal impact of strict budgetary rules decreases and finally disappears. If a country's government is capable and willing to commit, the marginal value added from stricter legally entrenched budgetary rules and procedures is small. Earlier studies analyzing the effect of budgetary institutions on fiscal outcomes did not control for the overall institutional framework to the extent that we do. Our results suggest that part of the effect of budget institutions on fiscal outcomes found by previous studies on advanced countries might actually capture differences in the overall institutional framework.

The above results offer at least three very interesting perspectives on the interaction between a country's broader institutional framework and the two major macroeconomic commitment institutions in their impact on macroeconomic outcomes. First of all, we observe that a better rule of law for elites has in general a beneficial impact on

\footnotetext{
again.

${ }^{31}$ Note that the sample size decreases for all specifications including doorstep indicators other than $d$ all. The changes may thus also be caused by the different sample size.
} 
macroeconomic outcomes (in our case inflation and external debt). Achieving this first doorstep condition seems to be the most critical one from a macroeconomic point of view. Secondly, strengthening the independence of a central bank seems to have a positive impact on lowering inflation irrespective of a country's position in the transition process described by NWW. Thus, the quality of the institutions (more specifically observance of the rule of law by the elites) and CBI have a separate, mutually reinforcing impact on macroeconomic outcomes. Thirdly, and in constrast with the second observation, budgetary rules and procedures have the greatest disciplining effect on fiscal policy in countries that have substandard levels of rule of law and perpetual organizations. Once the quality of the broader institutional framework increases, their disciplining impact on fiscal outcomes becomes stronger, and the marginal impact of BI diminishes. So, the observed interaction of the broader framework with CBI differs substantially from the impact on the effectiveness of BI.

To some extent, these findings also reflect the different characteristics of the two types of MCI. A central bank which is independent from the executive and committed to low inflation should be in a good position to enhance macroeconomic stability, even if the other political and economic institutions in the country are relatively weak. As an independent agency, the central bank wishes to establish credibility, both domestically and internationally, and will therefore strive to contain inflation. This is consistent with the thesis offered in Maxfield (1997) on the importance of CBI in developing countries.

$\mathrm{BI}$ on the other hand, is closely correlated with the overall institutional framework of a country. When introducing stricter rules into the budget process, these rules will not only affect budgetary procedures but indirectly also a number of other economic and political processes. Hence, in countries with a weak institutional environment, we would expect a spill-over effect from better budget institutions to other areas of government. The effect of $\mathrm{BI}$ on macroeconomic outcomes is therefore magnified in countries in the early stages of transition. But in countries approaching the transition to an open access society, the advanced broader institutional environment also shapes the quality of the de facto budget procedures. The marginal benefit from introducing (additional) formal rules and controls into the budget process of these countries will consequently diminish.

\section{Caveats and Robustness Checks ${ }^{32}$}

We are aware that the econometric analysis suffers from some problems that can only partially be remedied in this paper. First of all, the index captures the transition process described by NWW in the best possible way, but remains imperfect due to data limitations in existing institutional databases. As a test of robustness we also aggregated the eight categories into an overall indicator by obtaining the respective weights from Principal Component Analysis. The results are not affected in any significant way. Another weakness is potential endogeneity: in the second part of the analysis, fiscal and monetary policy outcomes could shape MCI and doorstep conditions. Thus, MCI and

\footnotetext{
${ }^{32}$ The results discussed in this section are available from the authors upon request.
} 
doorsteps could be endogenous to past and current levels of inflation and government debt levels. This, however, is a general weakness in all empirical analyses of this type.

A third issue is the potential omission of important variables. If we have omitted other institutional variables that drive CBI or BI in the first part, or fiscal and monetary outcomes in the second part, the effect of the doorstep indicators could be overstated. We therefore included a number of additional explanatory variables, including broad social and political institutional variables, such as fractionalization and a dummy for democracy. This did not affect our general findings. We also tested replacing our doorsteps indices by traditional institutional measures contained in our index, such as Constraints on the Executive (Polity IV) and Political Stability (IPD 2009) to find out if they drive our results. This is generally not the case and the coefficients of the alternative institutional measures are insignificant. Furthermore, we tested if our results hold across different sub-samples. We divided our sample into African and non-African countries and repeated the regressions. The results suggest that our general findings hold across different regional sub-samples.

A problem that cannot be solved in this paper is the lack of a time dimension in our analysis. We could only construct the doorsteps index for one (the most recent) point in time as several of the index components are based upon variables introduced in the 2009 version of the IPD database. However, this database is now being updated regularly. It would thus be interesting to update the doorsteps index on a regular basis and repeat the regressions for a panel dataset after a few years. This would allow controlling for country fixed effects and thereby for eliminating all unobserved time-invariant heterogeneity.

\section{CONCLUSION}

Macroeconomic commitment institutions have been promoted as institutional fixes for solving time-inconsistency problems in fiscal and monetary policymaking. So far, most research on their effectiveness has been conducted in the framework of advanced economies characterized by high quality institutional environments. However, MCI have also been introduced in LICs and MICs where they typically have to operate in a weaker institutional environment. The objective of this paper has been to analyze the impact of the institutional environment on (i) the decision to establish MCI and (ii) on their effectiveness in achieving desirable monetary and fiscal outcomes. In the measurement of the quality of the institutional environment we are inspired by NWW (2009) on the transition path from natural (or limited-access) states to open-access societies. We construct an index reflecting the three doorstep conditions defined by NWW (rule of law for the elites, perpetual forms of organizations, and political control of the military) and apply this to our two research questions in an experimental analysis.

Our findings for a sample of 77 LICs and MICs show that the establishment of independent central banks is not really influenced by the stage of transition the broader institutional framework is in, but rather by the level of income, and membership in a monetary union, and to some degree by external pressure. These results differ significantly from our findings on budget institutions which suggest that sound BI tend to be established in countries with a higher level of rule of law for the elites. 
Regarding effectiveness, we find that while the rule of law for the elites is associated with lower inflation, a country's position vis-à-vis the doorstep conditions does not have a significant impact on the effectiveness of CBI. CBI is negatively correlated with inflation irrespective of the broader institutional framework which has its own independent impact on containing inflation. This result stands in contrast with earlier findings suggesting that $\mathrm{CBI}$ is only effective in reducing inflation in more advanced countries.

Public external debt decreases with a country's transition across all three doorstep conditions. The effectiveness of sound budgetary institutions in reducing public external debt seems to decline as a country advances on the transition path towards the rule of law for the elites and the establishment of perpetual organizations. BI has the greatest impact on fiscal discipline in the weakest institutional environments. Once other disciplining devices are taking shape in the broader institutional framework, the marginal importance of strict fiscal rules and procedures decreases. Combining our two sets of results on BI brings out a paradox: good BI are needed the most where they are least likely to be established and needed least where they are most prominent. From this finding it could be inferred that budget reforms should be imposed externally. However, given the nature of budget institutions, it is doubtful whether external pressure can be effective-a point which is underlined by our first set of results.

A Slovenian proverb says "a doorstep is the highest of all mountains". Our findings suggest that this doorstep is the rule of law for the elites as defined by NWW. This condition, which is the starting point for a country's transition to an open access order, is critical not only in determining the quality of budget institutions but also for achieving low levels of inflation, debt and deficits. Compliance with a minimum level of rules and constraints seems to be a critical precondition for achieving a stable macroeconomic environment. 


\section{References}

Acemoglu, Daron and Simon Johnson. 2005. "Unbundling Institutions." Journal of Political Economy,

11:5.

, Simon Johnson, Pablo Querubin, and James A. Robinson. 2008. "When Does Policy Reform Work? The Case of Central Bank Independence." NBER Working Paper No. 14033. International Monetary Fund.

, Daron, Simon Johnson, James A. Robinson, and Yunyong Taicharoen. 2003. "Institutional causes, macroeconomic symptoms: volatility, crises and growth." Journal of Monetary Economics, 50, pp. 49-123.

, Daron and James A. Robinson. 2006. Economic Origins of Dictatorship and Democracy. Cambridge: Cambridge University Press.

Alesina, Alberto. 1988. "Macroeconomics and Politics." NBER Macroeconomic Annual: 13-52. MITPress: Cambridge, MA.

, Arnaud Devleeschauwer, William Easterly, Sergio Kurlat, and Romain Wacziarg. 2002."Fractionalization." NBER Working Paper 9411. National Bureau of Economic Reserach: Cambridge, MA.

, Alberto and Roberto Perotti. 1994. "The Political Economy of Budget Deficits." NBER Working Paper No. 4637. NBER: Cambridge, MA.

, and R. Perotti. 1996. "Budget Deficits and Budget Institutions." NBER Working Paper 5556.National Bureau of Economic Research: Cambridge, MA.

, Alberto and Guido Tabellini. 1990. "A Positive Theory of Fiscal Deficits and Government Debts." The Review of Economic Studies, 57:3, pp. 403-14.

, Alberto F., Ricardo Hausmann, Rudolf Hommes, and Ernesto H. Stein. 1999. "Budget Institutions and Fiscal Performance in Latin America." Journal of Development Economics, 59,pp. 253-73.

Alt, James E. and David Dreyer Lassen. 2003. "Fiscal Transparency and Fiscal Outcomes in OECD Countries." Economic Policy Research Unit, University of Copenhagen: Copenhagen. 
Arnone, Marco, Bernard Laurens, and Jean-François Segalotto. 2007. "Measures of Central Bank Autonomy: Empirical Evidence for OECD, Developing, and Emerging Market Economies."IMF Working Paper No. 06/228. International Monetary Fund.

Bade, Robin and Michael Parkin. 1982. "Central bank laws and inflation-a comparative analysis."mimeo. University of Western Ontario: London, Ontario.

Barro, Robert and David Gordon. 1983. "A positive theory of monetary policy in a natural-rate model."Journal of Political Economy, 91, pp. 589-610.

Beck, Thorsten, George Clarke, Alberto Groff, Philipp Keefer, and Patrick Walsh. 2001. "New tools in comparative political economy: The Database of Political Institutions." World Bank Economic Review, Vol. 15:1: 165-67.

Campos, Edward and Sanjay Pradhan. 1996. "Budgetary Institutions and Expenditure Outcomes: Binding Governments to Fiscal Performance." Policy Research Working Paper No. 1646. World Bank: Washington.

Crowe, Christopher and Ellen E. Meade. 2008. "Central Bank Independence and Transparency: Evolution and Effectiveness." IMF Working Paper No. 08/119 SSRN: Washington.

Cukierman, Alex. 1992. Central bank strategy, credibility, and independence: theory and evidence. Cambridge, MA; London: The MIT Press. , 1994. "Central Bank Independence and Monetary Control " Economic Journal, 104:427, pp. 1437-48.

, Pantelis Kalaitzidakis, Lawrence H. Summers, and Steven B. Webb. 1993. "Central bank independence, growth, investment, and real rates." CarnegieRochester Conference Series on Public Policy, 39 1, pp. 95-140.

, Steven B Webb, and Bilin Neyapti. 1992. "Measuring the Independence of Central Banks and Its Effect on Policy Outcomes " World Bank Economic Review, 6:3, pp. 353-98.

Dabla-Norris, Era, Richard Allen, Luis-Felipe Zanna, Tej Prakash, Eteri Kvitradze, Victor Lledo, Irene Yackovlev, and Sophia Gollwitzer. 2010. "Budget Institutions and Fiscal Performance in Low-Income Countries." IMF WP/10/80. International Monetary Fund: Washington. 
De Crombrugghe, Denis, Kristine Farla, Nicolas Meisel, Chris de Neubourg, Jacques Ould Aoudia, and Adam Szirma. 2006. "Institutional Profiles Database." CEPII.

De Haan, Jakob and Clemens L.J. Siermann. 1996. "Central bank independence, inflation and political instability in developing countries." Journal of Economic Policy Reform, 1:2, pp. 135 - 47.

Eggertson, Thráinn. 2005. Imperfect Institutions: Possibilities \& Limits of Reform: Ann Arbor: The University of Michigan Press.

Eijffinger, Sylvester and Patrick Stadhouder. 2003. "Monetary Policy and the Rule of Law." CEPR Discussion Paper Series. Centre for Economic Policy Research.

Estache, Antonio and Liam Wren-Lewis. 2009. "Toward a Theory of Regulation for Developing Countries: Following Jean-Jacques Laffont's Lead." Journal of Economic Literature, 47:3, pp. 729-70.

Fabrizio, Stefania and Ashoka Mody. 2006. "Can Budget Institutions Counteract Political Indiscipline?" IMF WP/06/123. International Monetary Fund: Washington, D.C.

Fergusson, Niall and Moritz Schularick. 2008. "The "Thin Film of Gold": Monetary Rules and Policy Credibility in Developing Countries." NBER Working Paper. National Bureau of Economic Research: Cambridge, MA.

Fry, Maxwell, Charles A E. Goodhart, and Alvaro Almeida. 1996. Central Banking in Developing Countries. New York: Routledge.

Fukuyama, Francis. 1995. "Trust: The social virtues and creation of prosperity." New York, NY.

Gollwitzer, Sophia. 2010. "Central Bank Independence in Africa." International Economics Department. The Graduate Institute of International and Development Studies: Geneva.

Grilli, Vittorio, Donate Masciandaro, and Guido Tabellini. 1991. "Political and Monetary Institutions and Public Financial Policies in the Industrial Countries." Economic Policy, 13, pp. 341-92.

Gutierrez, Eva. 2003. "Inflation Performance and Constitutional Central Bank Independence: Evidence From Latin America and the Caribbean." IMF Working Paper No. 03/53 International Monetary Fund: Washington, D.C. 
Gwartney, James, Robert Lawson, Herbert Grubel, Jacob de Haan, Jan-Egbert Sturm, and Eelco Zandberg. 2009. "Economic Freedom of the World: 2009 Annual Report." Vancouver, BC.

Hallerberg, Mark, Rolf Strauch, and Jürgen Von Hagen. 2004. "The Design of Fiscal Rules and Forms of Governance in European Union Countries." ECB Working Paper No. 419 European Central Bank: Frankfurt.

, and Jürgen Von Hagen. 1999. "Electoral Institutions, Cabinet Negotiations, and Budget Deficits within the European Union," in Fiscal Institutions and Fiscal Performance. James Poterba and Jürgen von Hagen eds. Chicago: University of Chicago Press, pp. 209-32.

Harden, Ian and Jürgen Von Hagen. 1994. "National Budget Processes and Fiscal Performance." European Economy Reports and Studies, 3, pp. 311-418.

Huang, Haihou and Shang-Jin Wei. 2006. "Monetary policies for developing countries: The role of institutional quality." Journal of International Economics, 70, pp. 239-52.

Jacome, Luis and F. Vazquez, 2008. "Is there any Link between Legal Central Bank Independence and Inflation? Evidence from Latin America and the Caribbean." European Journal of Political Economy, Vol. 24, no.4, pp. 788 - 801.

Keefer, Philip and Stephen Knack. 1997. "Why don't poor countries catch up? A crossnational test of an institutional explanation." Economic Inquiry, XXXV: July 1997, pp. 590-602. , and David Stasavage. 2001. "Bureaucratic Delegation and Political Institution: When are Independent Central Banks Irrelevant?" World Bank Policy Research Working Paper No. 2356 World Bank: Washington, D.C.

Kydland, Finn and Edward Prescott. 1977. "Rules rather than discretion: The inconsistency of optimal plans." Journal of Political Economy, 85, pp. 473-90.

Laffont, Jacques. 2005. Regulation and Development. Cambridge: Cambridge University Press.

Lybek, Tonny. 1999. "Central Bank Autonomy, and Inflation and Output Performance in the Baltic States, Russia, and Other Countries of the Former Soviet Union, 199597." IMF Working Paper No. 99/4. International Monetary Fund: Washington. 
Marshall, Monty G. and Keith Jaggers. 2008. "Polity IV Project: Political Regime Characteristics and Transitions, 1800-2008." Center for Systemic Peace.

Maxfield, S., 1997, Gatekeepers of Growth. The international political economy of central banking in developing countries. Princeton, Princeton University Press.

McCallum, Bennett T. 1995, “Two Fallacies concerning central bank independence." American Economic Review, Papers and Proceedings, 85, pp. 207-211.

Mulas-Granados, Carlos, Jorge Onrubia, and Javier Salinas-Jeménez. 2009. "Do Budget Institutions Matter? Fiscal Consolidation in the New EU Member States." Eastern European Economics 47:1, pp. 60-91.

North, Douglass C. 1988. "Institutions and economic growth: A historical introduction," in Freedom, democracy, and economic welfare. Michael A. Walker ed. Canada: Fraser Institute.

, 1990. Institutions, Institutional Change and Economic Performance. Cambridge: Cambridge University Press. , 2005. Understanding the Process of Economic Change. Princeton: Princeton University Press.

, John Joseph Wallis, and Barry R. Weingast. 2006. "A Conceptual Framework for Interpreting Recorded Human History." NBER Working Paper No. 12795. National Bureau of Economic Research: Cambridge, MA. , John Joseph Wallis, and Barry R. Weingast. 2009. Violence and Social Orders. Cambridge: Cambridge University Press.

Quintyn, Marc. 2009. "Independent agencies: more than a cheap copy of independent central banks?" Constitutional Political Economy, 20(3):Springer, pp. 267-95.

Rogoff, Kenneth. 1985. "The Optimal Degree of Commitment to an Intermediate Monetary Target”. Quarterly Journal of Economics 100, pp. 1169-1190.

Schick, Allen. 1998. A Contemporary Approach to Public Expenditure Management: World Bank Institute.

Schumpeter, Joseph A. 1942. Capitalism, Socialism and Democracy. New York, NY: Harper Perennial Modern Thought. 
The International Institute for Strategic Studies. 2009. "Armed Conflict Database." IISS.

Von Hagen, Jürgen. 1992. "Budgeting Procedures and Fiscal Performance in the European Communities " European Economy - Economic Papers, Vol. 96. Commission of the EC, Directorate-General for Economic and Financial Affairs (DG ECFIN).

Weber, Max. 1947. The Theory of Social and Economic Organization. New York, NY: The Free Press.

Weingast, Barry R. 2002. "Rational Choice Institutionalism," in Political Science: The State of the Discipline. Ira Katznelson and Helen V. Milner eds. New York, NY: W. W. Norton Company Inc., pp. 660-92. 
Figure 1: Country Rankings and Doorsteps: D1

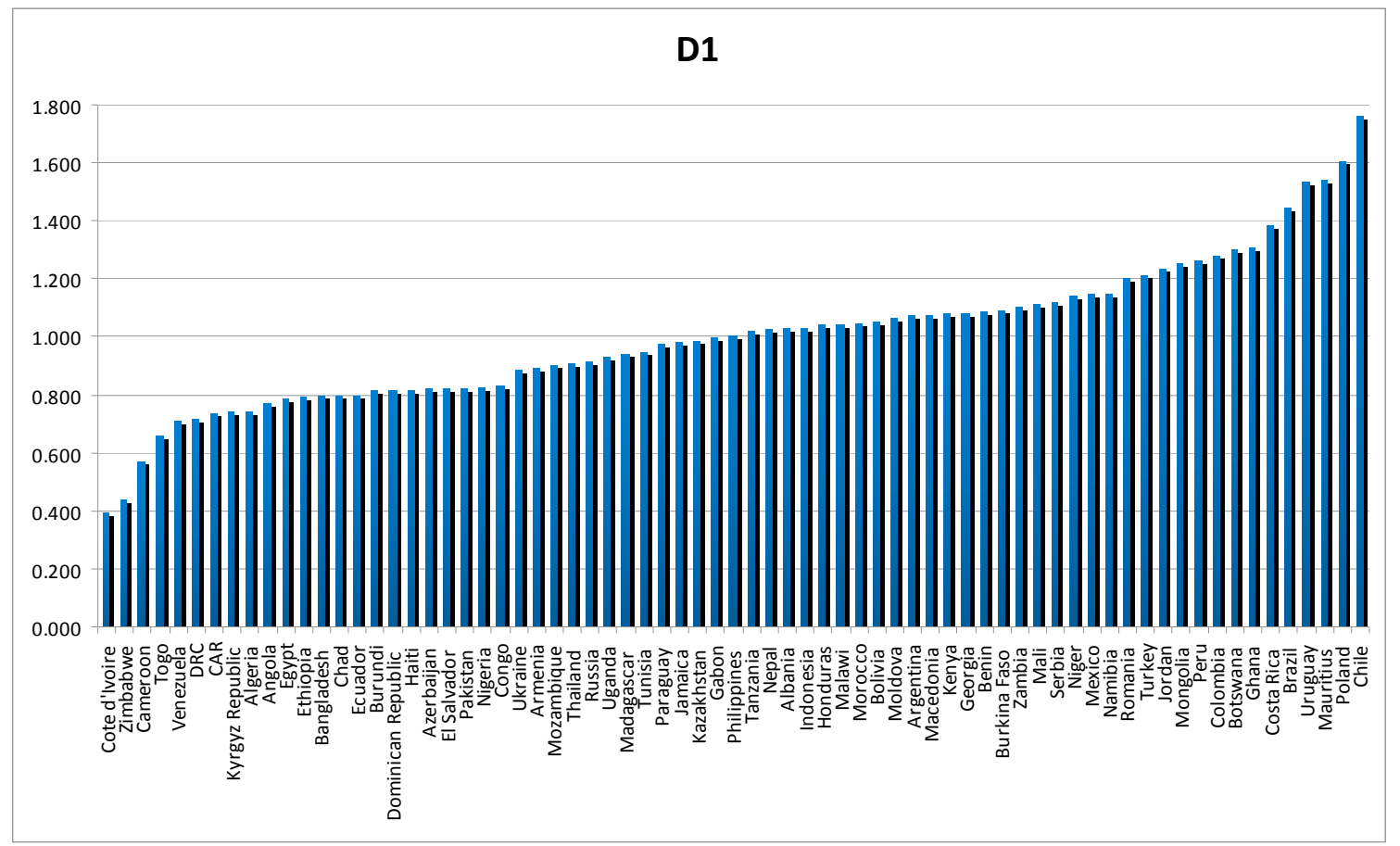

Figure 2: Country Rankings and Doorsteps: D2

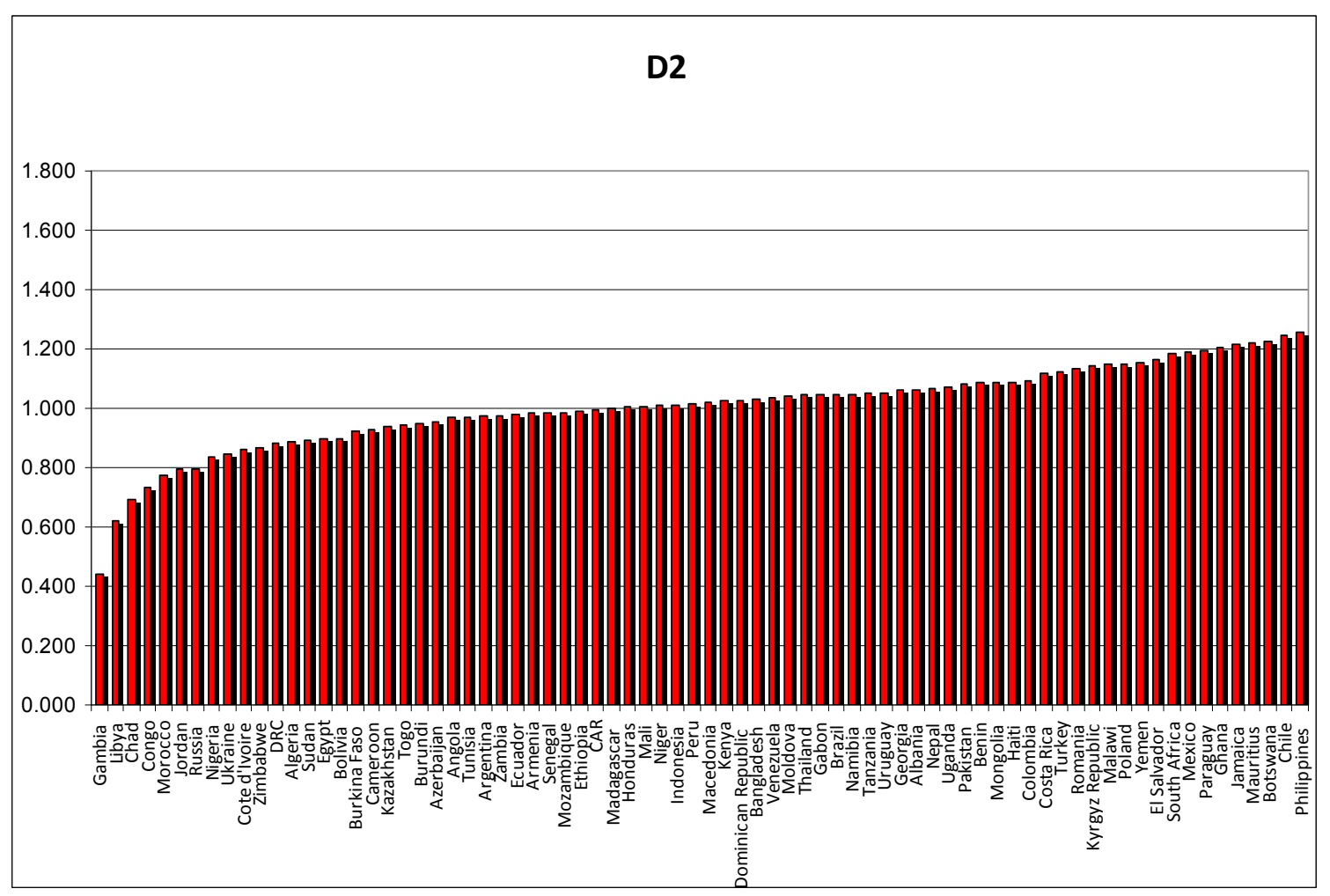


Figure 3: Country Rankings and Doorsteps: D3

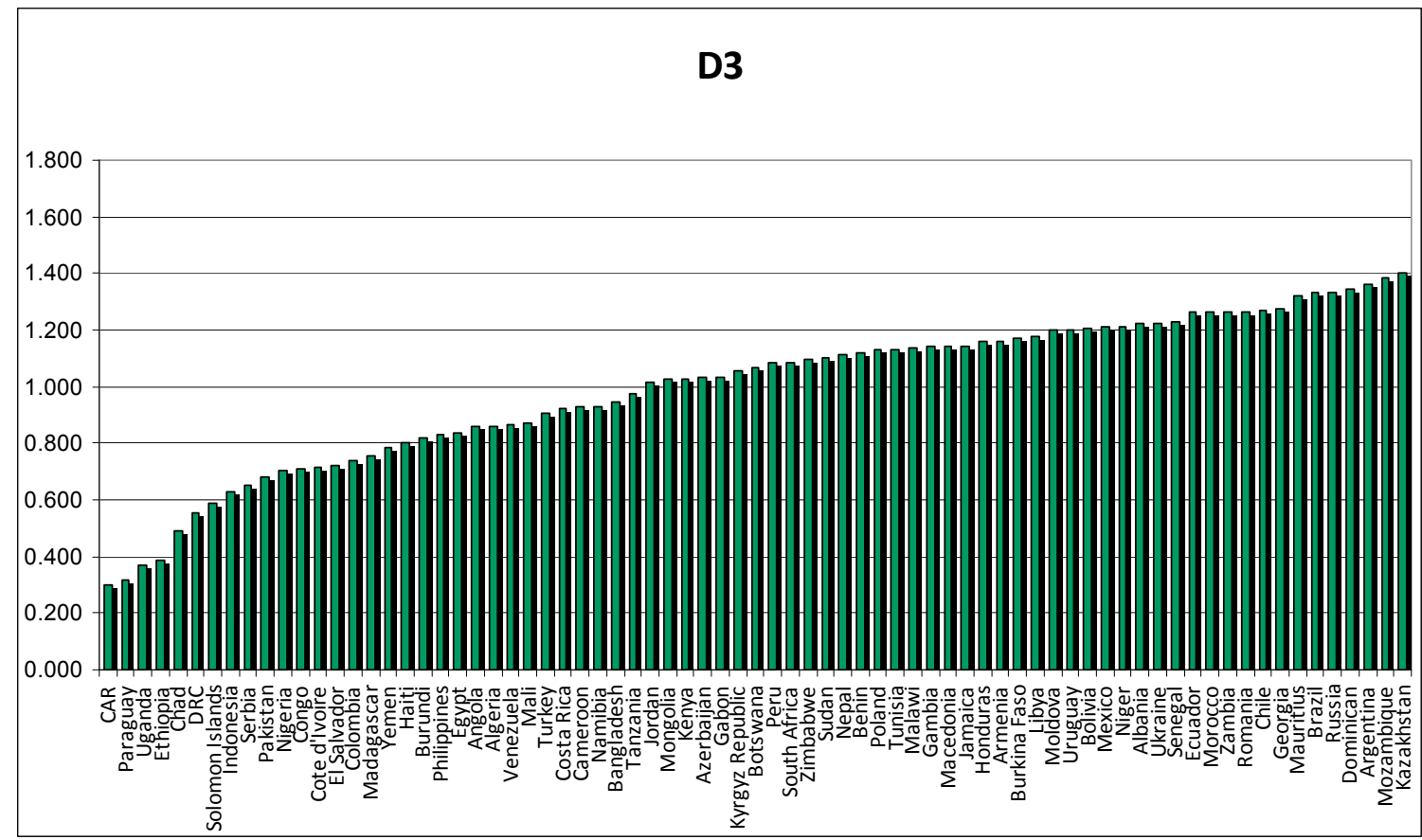

Figure 4: Scatter plot of overall Doorsteps and CBI

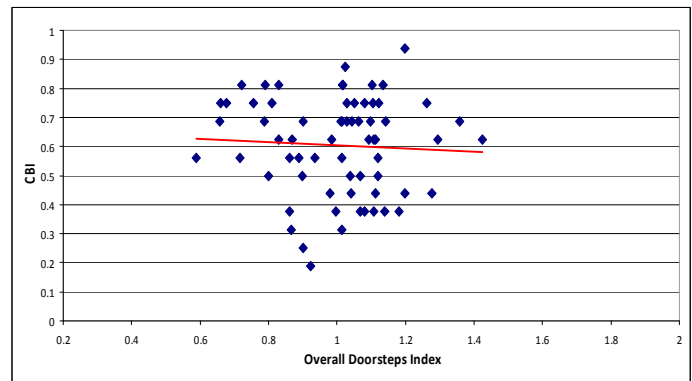

Figure 5: Scatter plot of D1 and CBI

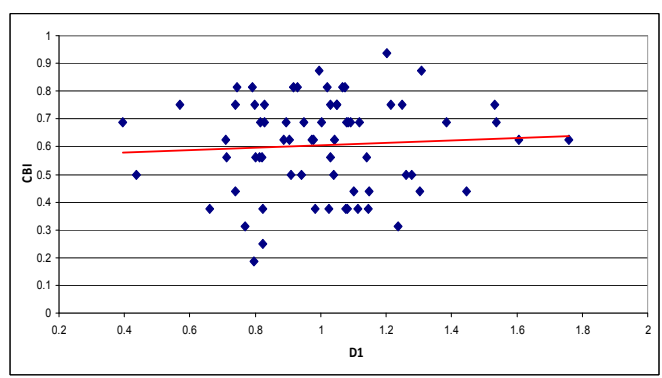


Figure 6: Scatter plot of D2 and CBI

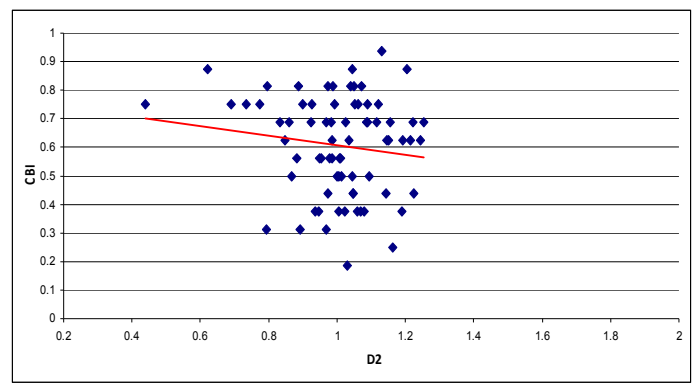

Figure 7: Scatter plot of D3 and CBI

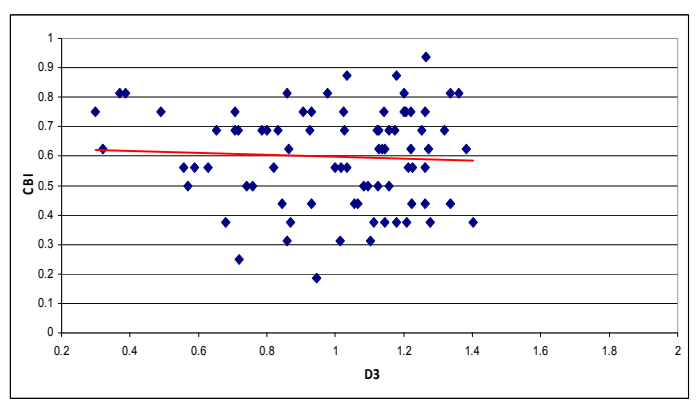

Figure 8: Scatter plot of overall Doorsteps and BI

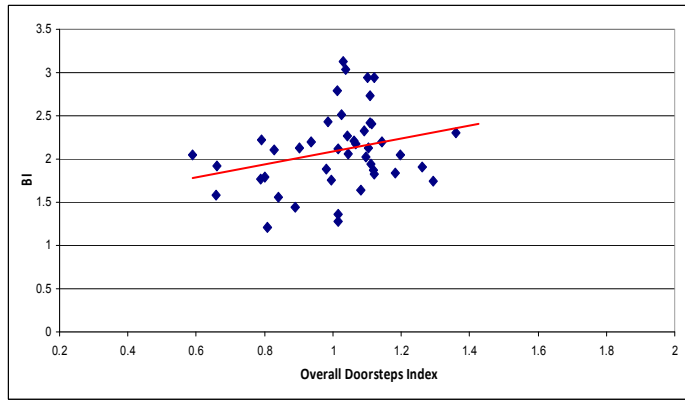

Figure 9: Scatter plot of D1 and BI

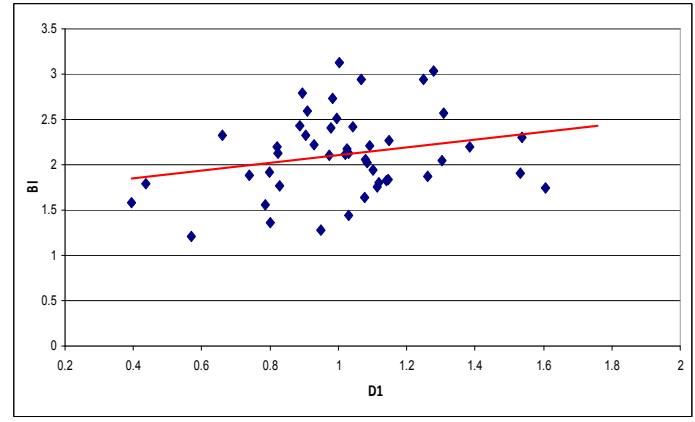

CInternational Monetary Fund. Not for Redistribution 
Figure 10: Scatter plot of D2 and BI

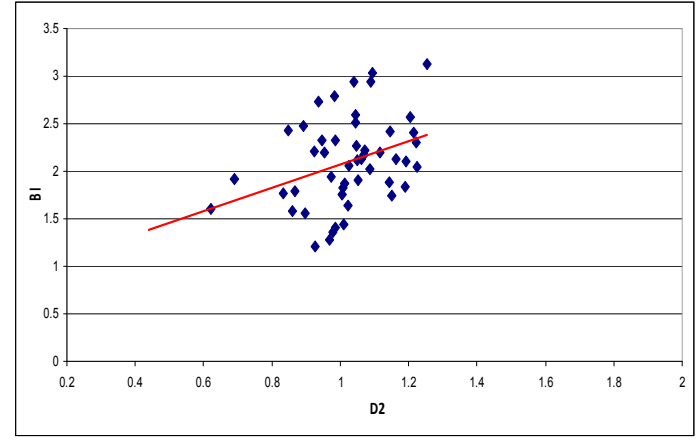

Figure 11: Scatter plot of D3 and BI

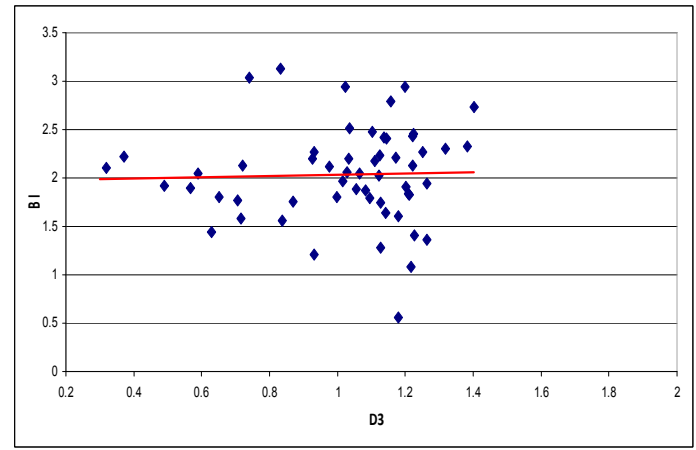


Figures 12: The Effectiveness of CBI for Low D1 (a through e) and High D1 (f through $\mathbf{j}$ )

Figure 12.a: Without D (low D1)

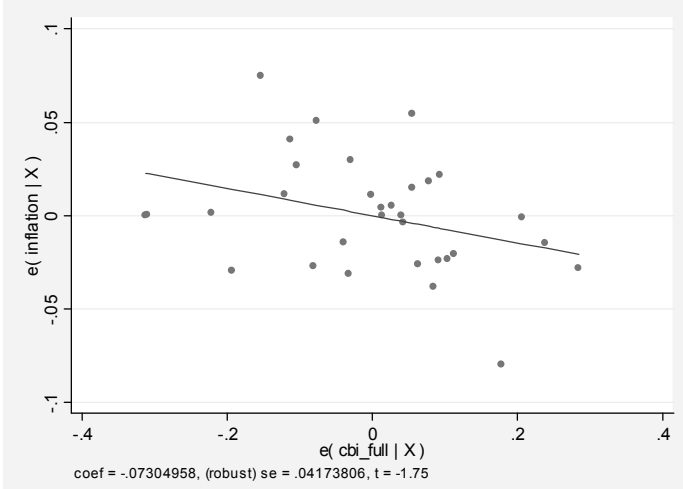

Figure 12.b: With D_All (low D1)

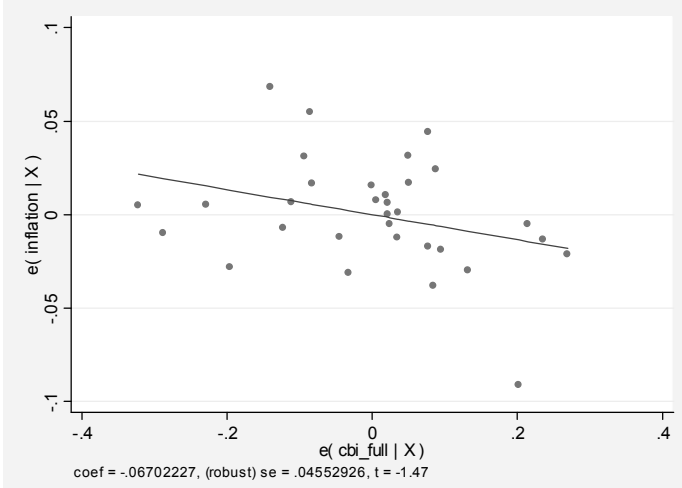

Figure 12.c: With D1 (low D1)

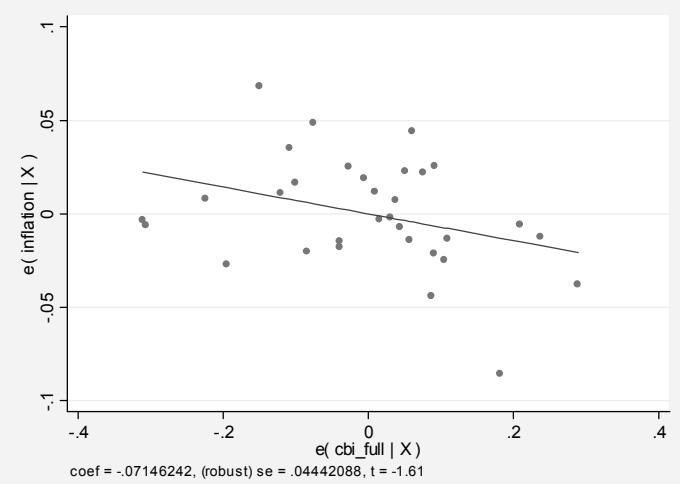


Figure 12.d: With D1D2 (low D1)

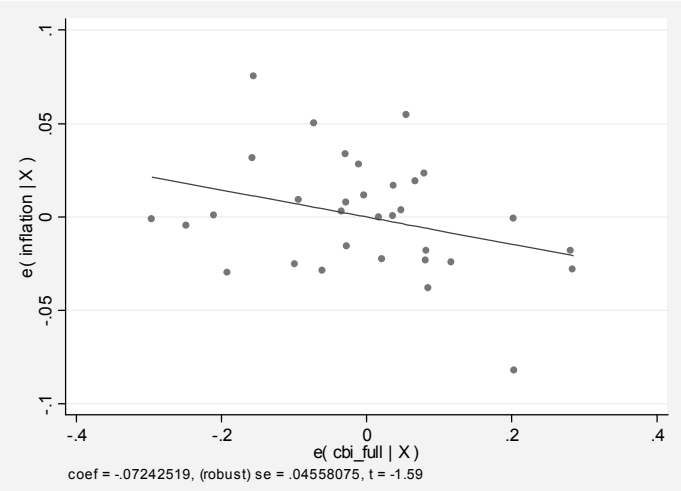

Figure 12.e: With D1D2D3 (low D1)

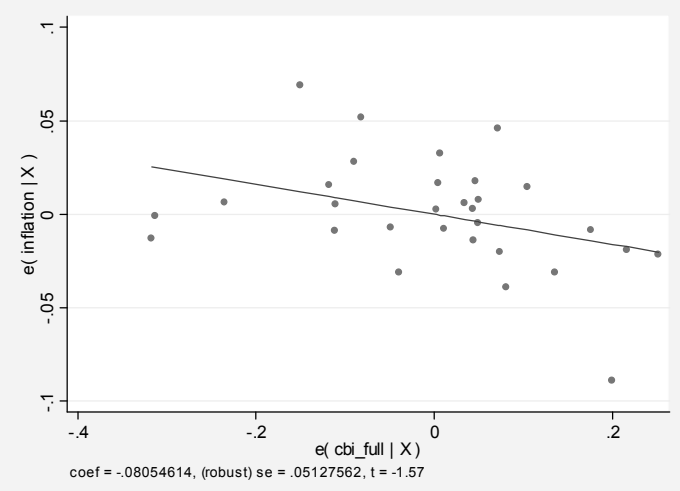

Figure 12.f: Without D (high D1)

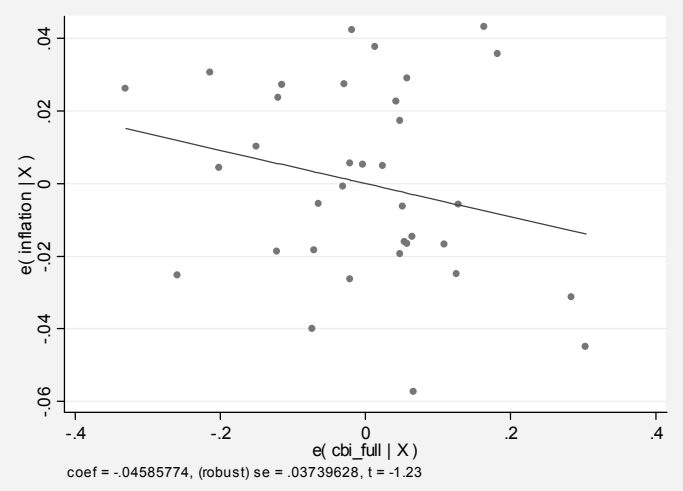


39

Figure 12.g: With D_All (high D1)

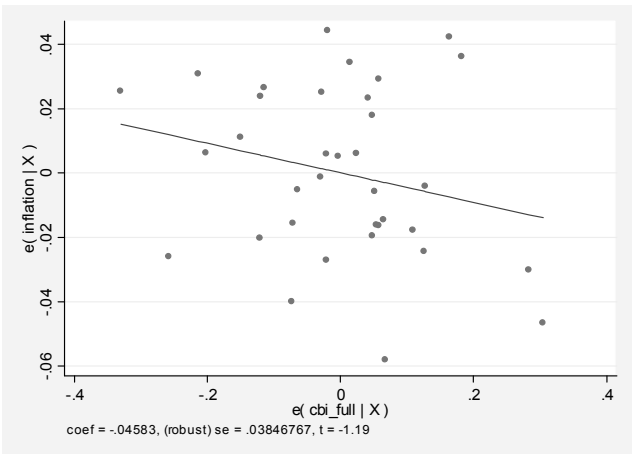

Figure 12.h: With D1 (high D1)

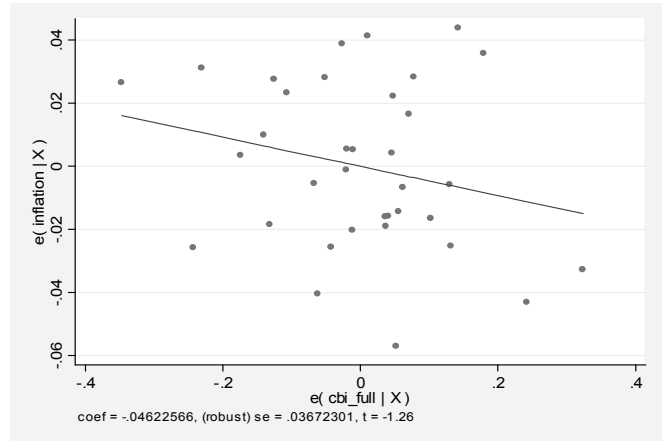

Figure 12.i: With D1D2 (high D1)

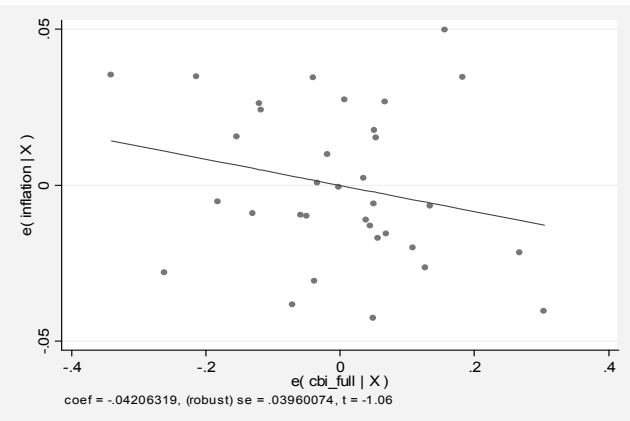

Figure 12.j: With D1D2D3 (high D1)

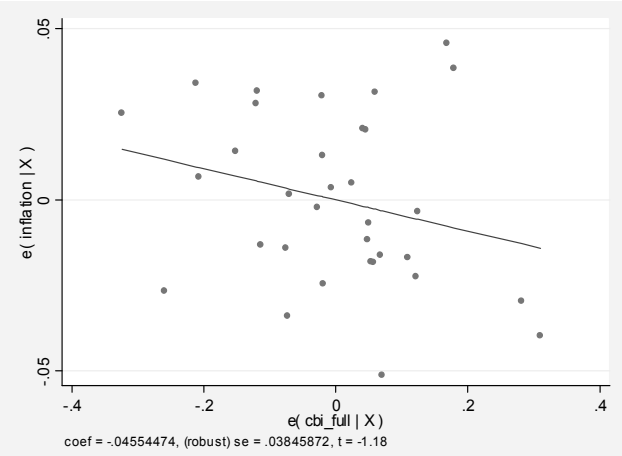

(C) International Monetary Fund. Not for Redistribution 
Figure 13.a: Marginal Effect of BI on PED (varying D1)

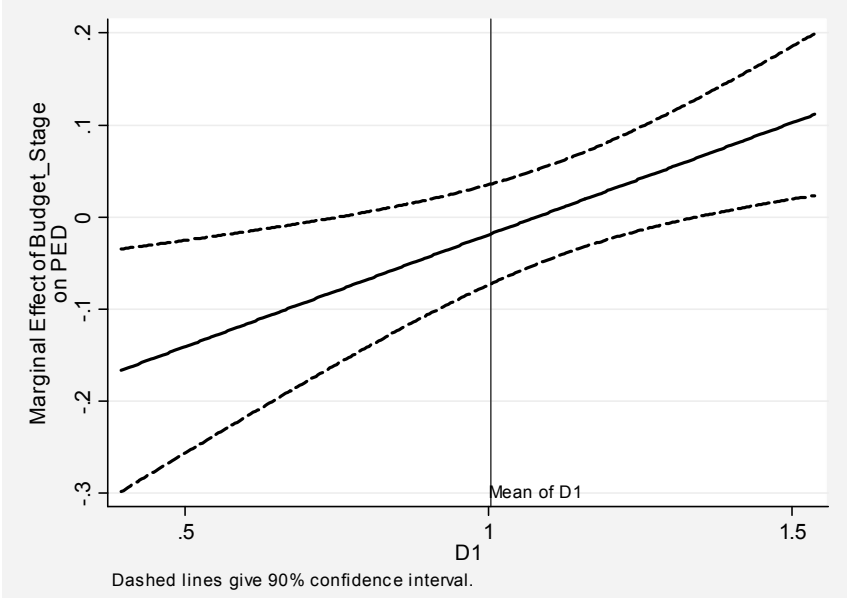

Figure 13.b: Marginal Effect of BI on PED (varying D1D2)

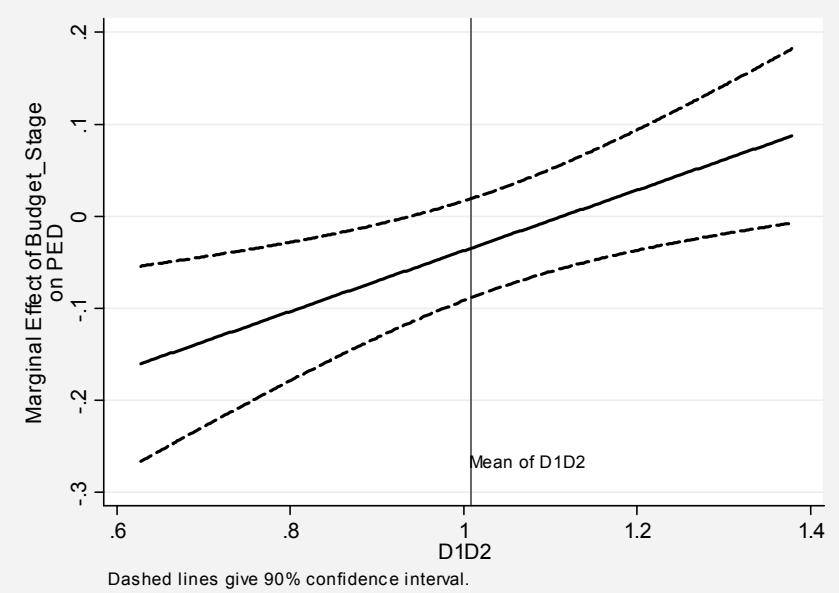

Figure 13.c: Marginal Effect of BI on PED (varying D1D2D3)

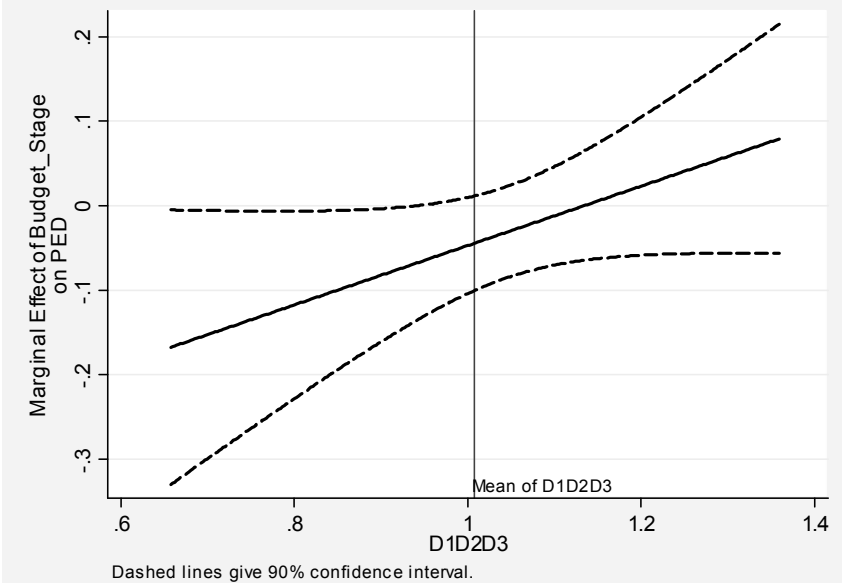


Figure 14: The Effectiveness of BI for Low D1 (a through e) And High D1 (f through j)

Figure 14.a: Without D (low D1)

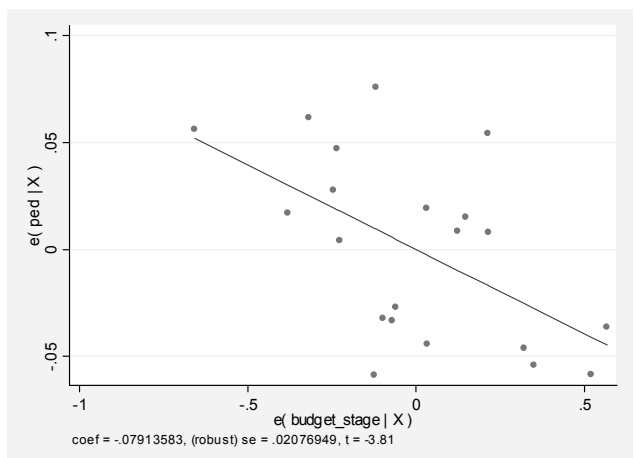

Figure 14.b: With D_All (low D1)

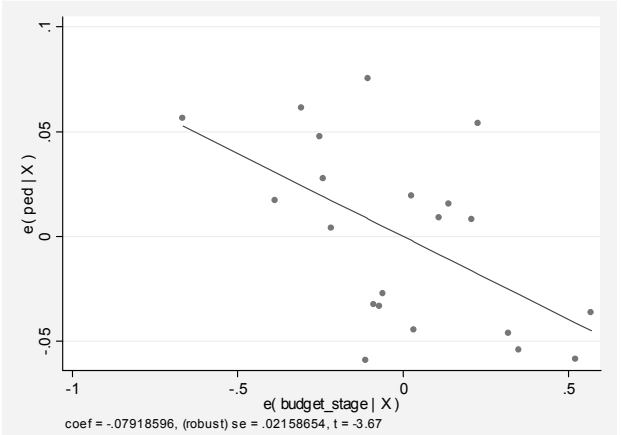

Figure 14.c: With D1 (low D1)

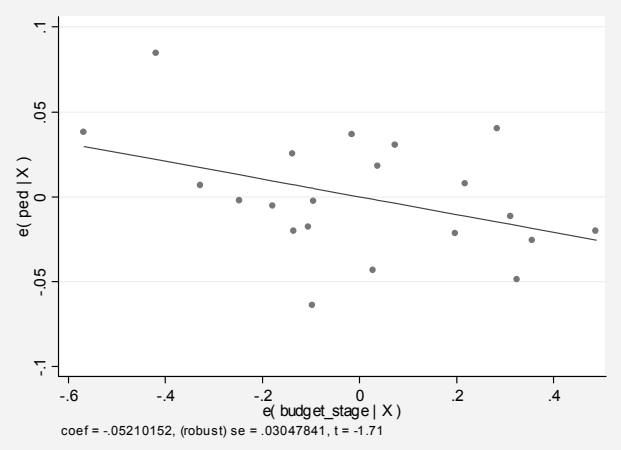

Figure 14.d: With D1D2 (low D1)

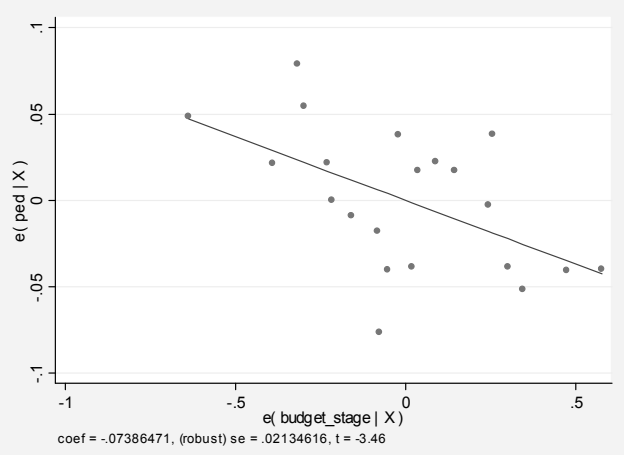

(CInternational Monetary Fund. Not for Redistribution 
Figure 14.e: With D1D2D3 (low D1)

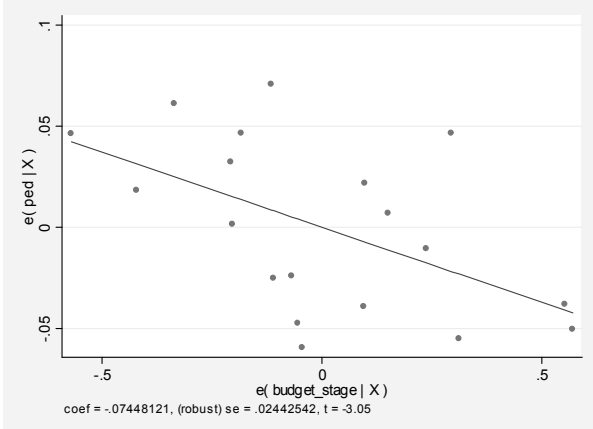

Figure 14.f: Without D (high D1)

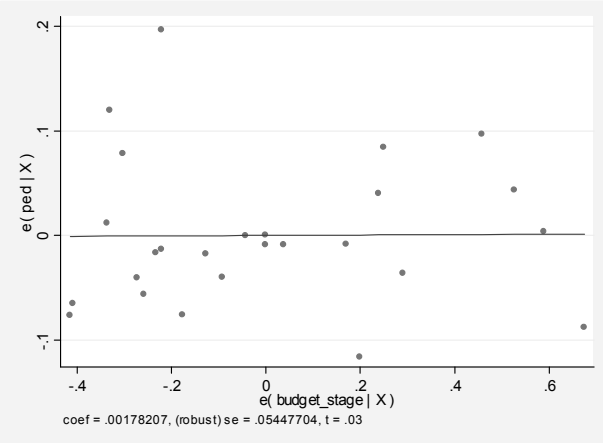

Figure 14.g: With D_All (high D1)

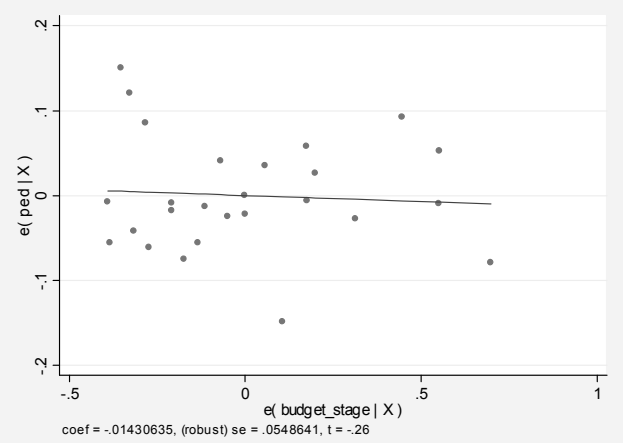

Figure 14.h: With D1 (high D1)

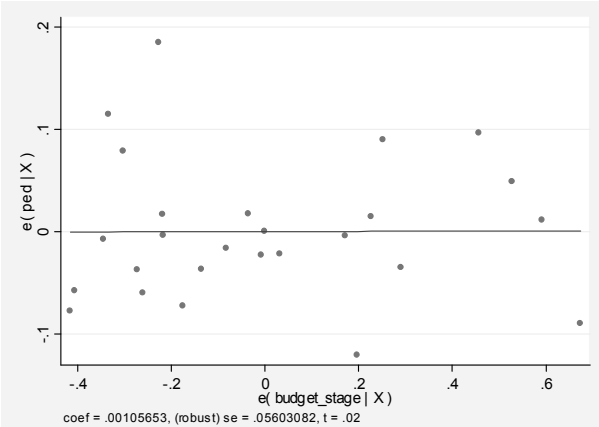

CInternational Monetary Fund. Not for Redistribution 
Figure 14.i: With D1D2 (high D1)

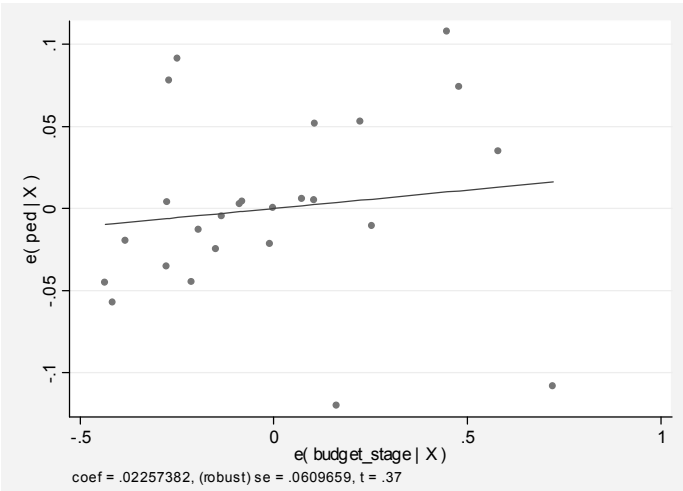

Figure 14.j: With D1D2D3 (high D1)

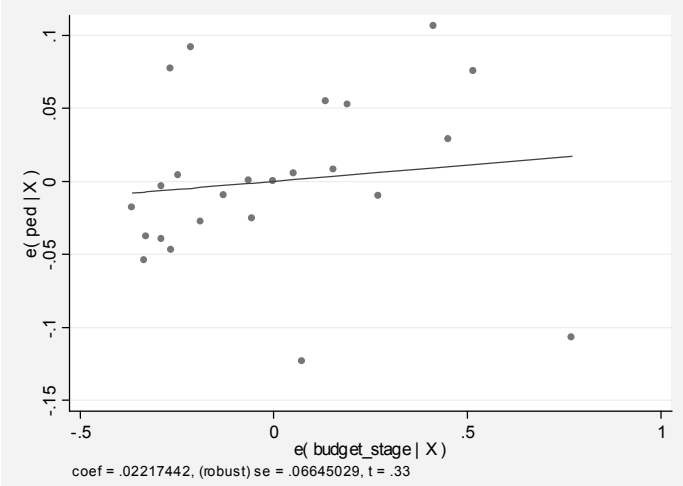


Table 4: Spearman Rank Correlations among Sub-Indices

\begin{tabular}{||l|l|l|l||}
\hline \hline & DOORSTEP1 & DOORSTEP2 & DOORSTEP3 \\
\hline Doorstep1 & 1.00 & & \\
\hline Doorstep2 & 0.50 & 1.00 & \\
& $(0.00)$ & & \\
\hline Doorstep3 & 0.40 & -0.01 & 1.00 \\
& $(0.00)$ & $(0.95)$ & \\
\hline
\end{tabular}

$P$-values in brackets

Table 5: Average Index Values per Income Group

\begin{tabular}{||l|l|l|l|l|l|l|l|l|l|l|l|l||}
\hline & $\mathrm{D} 1-1$ & $\mathrm{D} 1-2$ & $\mathrm{D} 1-3$ & $\mathrm{D} 1$ & $\mathrm{D} 2-1$ & $\mathrm{D} 2-2$ & $\mathbf{D 2}$ & $\mathrm{D} 3-1$ & $\mathrm{D} 3-2$ & $\mathrm{D} 3-3$ & D3 & Total \\
\hline LIC & 0.54 & 0.34 & 0.48 & $\mathbf{0 . 9 0}$ & 0.68 & 0.61 & $\mathbf{0 . 9 8}$ & 0.74 & 0.58 & 0.49 & $\mathbf{0 . 9 1}$ & $\mathbf{0 . 9 2}$ \\
& $(0.20)$ & $(0.11)$ & $(0.17)$ & $\mathbf{( 0 . 2 2 )}$ & $(0.11)$ & $(0.08)$ & $\mathbf{( 0 . 1 5 )}$ & $(0.10)$ & $(0.32)$ & $(0.24)$ & $\mathbf{( 0 . 3 0 )}$ & $(\mathbf{0 . 1 6})$ \\
\hline LMIC & 0.53 & 0.37 & 0.51 & $\mathbf{0 . 9 4}$ & 0.66 & 0.57 & $\mathbf{0 . 9 8}$ & 0.82 & 0.57 & 0.55 & $\mathbf{0 . 9 8}$ & $\mathbf{0 . 9 6}$ \\
& $(0.22)$ & $(0.12)$ & $(0.11)$ & $\mathbf{( 0 . 1 6 )}$ & $(0.13)$ & $(0.12)$ & $\mathbf{( 0 . 1 3 )}$ & $(0.22)$ & $(0.31)$ & $(0.24)$ & $\mathbf{( 0 . 2 6})$ & $(\mathbf{0 . 1 2})$ \\
\hline UMIC & 0.74 & 0.45 & 0.62 & $\mathbf{1 . 1 8}$ & 0.75 & 0.63 & $\mathbf{1 . 0 6}$ & 0.84 & 0.72 & 0.64 & $\mathbf{1 . 1 1}$ & $\mathbf{1 . 1 3}$ \\
& $(0.20)$ & $(0.15)$ & $(0.20)$ & $\mathbf{( 0 . 2 8})$ & $(0.12)$ & $(0.12)$ & $\mathbf{( 0 . 1 5 )}$ & $(0.17)$ & $(0.20)$ & $(0.21)$ & $(\mathbf{0 . 2 1})$ & $(\mathbf{0 . 1 4})$ \\
\hline
\end{tabular}

Standard deviations in brackets

Table 6: Regression results of Doorsteps and CBI

\begin{tabular}{||l|l|l|l|l|l||}
\hline & WITHOUT D & WITH D_ALL & WITH D1 & WITH D1D2 & WITH D1D2D3 \\
\hline VARIABLES & cbi & cbi & cbi & cbi & cbi \\
\hline prgf & 0.0768 & 0.0848 & 0.0760 & 0.0782 & 0.0916 \\
\hline & $(0.0513)$ & $(0.0553)$ & $(0.0535)$ & $(0.0552)$ & $(0.0642)$ \\
\hline gdppc_2002 & $0.0695^{* * *}$ & $0.0777^{* * *}$ & $0.0725^{* * *}$ & $0.0722^{* *}$ & $0.0829^{* *}$ \\
\hline & $(0.0243)$ & $(0.0268)$ & $(0.0256)$ & $(0.0272)$ & $(0.0313)$ \\
\hline revenue & -0.310 & -0.320 & -0.177 & -0.231 & -0.230 \\
\hline & $(0.224)$ & $(0.225)$ & $(0.297)$ & $(0.307)$ & $(0.315)$ \\
\hline mu & $0.146^{* * *}$ & $0.140^{* * *}$ & $0.128^{* * *}$ & $0.128^{* *}$ & $0.112^{* *}$ \\
\hline & $(0.0407)$ & $(0.0434)$ & $(0.0467)$ & $(0.0484)$ & $(0.0523)$ \\
\hline d_all & & -0.0834 & & & \\
\hline & & $(0.121)$ & & & \\
\hline d1 & & -0.0442 & & \\
\hline & & & $(0.0924)$ & & \\
\hline d1d2 & & & & -0.0702 & \\
\hline & & & & $0.147)$ & \\
\hline d1d2d3 & & & & & -0.109 \\
\hline & & & 0.0564 & 0.0953 & $0.145)$ \\
\hline Constant & 0.0504 & 0.0685 & $(0.214)$ & $(0.227)$ & $(0.235)$ \\
\hline & $(0.202)$ & $(0.208)$ & 65 & 64 & 61 \\
\hline Observations & 71 & 71 & 0.163 & 0.166 & 0.173 \\
\hline R-squared & 0.183 & 0.188 & & \\
\hline
\end{tabular}

Robust standard errors in parentheses $* * * p<0.01, * * p<0.05,{ }^{*} p<0.1$ 
Table 7: Regression results of Doorsteps and the Budget Index

\begin{tabular}{|c|c|c|c|c|c|}
\hline & "WITHOUT D & בWITH D ALL & "WITH D1 & "WITH D1D2 & "WITH D1D2D3 \\
\hline VARIABLES & budget stage & budget stage & budget stage & $\overline{\text { budget stage }}$ & budget stage \\
\hline \multirow{2}{*}{ prgf } & 0.283 & 0.279 & 0.140 & 0.149 & 0.0977 \\
\hline & $(0.180)$ & $(0.198)$ & $(0.134)$ & $(0.148)$ & $(0.168)$ \\
\hline \multirow[t]{2}{*}{ gdppc_2002 } & $0.197 * *$ & $0.194^{*}$ & 0.0562 & 0.0930 & 0.0822 \\
\hline & $(0.0901)$ & $(0.0993)$ & $(0.0710)$ & $(0.0717)$ & $(0.0792)$ \\
\hline \multirow[t]{2}{*}{$\mathrm{mu}$} & -0.194 & -0.192 & $-0.223^{*}$ & $-0.240^{*}$ & -0.210 \\
\hline & $(0.136)$ & $(0.132)$ & $(0.111)$ & $(0.130)$ & $(0.137)$ \\
\hline \multirow[t]{2}{*}{ oil } & $-0.299 * *$ & $-0.296^{* *}$ & -0.151 & -0.214 & $-0.286^{*}$ \\
\hline & $(0.125)$ & $(0.127)$ & $(0.144)$ & $(0.159)$ & $(0.150)$ \\
\hline \multirow[t]{2}{*}{ d_all } & & 0.0429 & & & \\
\hline & & $(0.390)$ & & & \\
\hline \multirow[t]{2}{*}{$\mathrm{d} 1$} & & & $0.755 * *$ & & \\
\hline & & & $(0.328)$ & & \\
\hline \multirow[t]{2}{*}{$\mathrm{d} 1 \mathrm{~d} 2$} & & & & 0.481 & \\
\hline & & & & $(0.475)$ & \\
\hline \multirow[t]{2}{*}{$\mathrm{d} 1 \mathrm{~d} 2 \mathrm{~d} 3$} & & & & & 0.0825 \\
\hline & & & & & $(0.431)$ \\
\hline \multirow[t]{2}{*}{ Constant } & 0.477 & 0.459 & 0.903 & 0.896 & $1.425^{* *}$ \\
\hline & $(0.789)$ & $(0.786)$ & $(0.572)$ & $(0.640)$ & $(0.567)$ \\
\hline Observations & 51 & 51 & 47 & 46 & 43 \\
\hline R-squared & 0.177 & 0.177 & 0.275 & 0.189 & 0.126 \\
\hline
\end{tabular}

Robust standard errors in parentheses $* * * p<0.01, * * p<0.05, * p<0.1$ 
Table 8: Regression results of Doorsteps and the impact of CBI

\begin{tabular}{|c|c|c|c|c|c|}
\hline & WITHOUT D & $\begin{array}{l}\text { WITH D_ALL } \\
\end{array}$ & $\begin{array}{l}\text { WITH D1 } \\
\end{array}$ & $\overline{\text { WITH D1D2 }}$ & $\begin{array}{l}\text { WITH } \\
\text { D1D2D3 }\end{array}$ \\
\hline VARIABLES & Inflation & inflation & inflation & inflation & inflation \\
\hline \multirow[t]{2}{*}{ cbi } & $-0.0616^{* *}$ & $-0.0605 * *$ & $-0.0798 * * *$ & $-0.0791 * * *$ & $-0.0831 * * *$ \\
\hline & $(0.0276)$ & $(0.0279)$ & $(0.0292)$ & $(0.0294)$ & $(0.0305)$ \\
\hline \multirow[t]{2}{*}{ gdppc_2002 } & $-0.0157 * *$ & $-0.0146^{* *}$ & -0.00868 & -0.0108 & -0.00745 \\
\hline & $(0.00659)$ & $(0.00666)$ & $(0.00731)$ & $(0.00745)$ & $(0.00822)$ \\
\hline \multirow[t]{2}{*}{$\mathrm{mu}$} & $-0.0549^{* * *}$ & $-0.0560 * * *$ & $-0.0529 * * *$ & $-0.0533 * * *$ & $-0.0529 * * *$ \\
\hline & $(0.00984)$ & $(0.00988)$ & $(0.00982)$ & $(0.0111)$ & $(0.0103)$ \\
\hline \multirow[t]{2}{*}{ umi } & 0.0205 & 0.0229 & $0.0319^{* *}$ & 0.0258 & 0.0228 \\
\hline & $(0.0134)$ & $(0.0145)$ & $(0.0148)$ & $(0.0164)$ & $(0.0159)$ \\
\hline \multirow[t]{2}{*}{ oil } & 0.0128 & 0.0106 & -0.00217 & 0.00394 & 0.00406 \\
\hline & $(0.00962)$ & $(0.00904)$ & $(0.00980)$ & $(0.0114)$ & $(0.0100)$ \\
\hline \multirow[t]{2}{*}{ ped 2002} & -0.00230 & -0.00150 & 0.0132 & 0.00998 & 0.00770 \\
\hline & $(0.0119)$ & $(0.0121)$ & $(0.0136)$ & $(0.0140)$ & $(0.0162)$ \\
\hline \multirow[t]{2}{*}{ growth } & 0.116 & 0.122 & 0.166 & 0.142 & 0.138 \\
\hline & $(0.204)$ & $(0.206)$ & $(0.208)$ & $(0.212)$ & $(0.216)$ \\
\hline \multirow[t]{2}{*}{ trade } & $0.182^{*}$ & $0.181^{*}$ & $0.200^{*}$ & $0.188^{*}$ & $0.193^{*}$ \\
\hline & $(0.103)$ & $(0.102)$ & $(0.101)$ & $(0.108)$ & $(0.110)$ \\
\hline \multirow[t]{2}{*}{ d_all } & & -0.0218 & & & \\
\hline & & $(0.0291)$ & & & \\
\hline \multirow[t]{2}{*}{$\mathrm{d} 1$} & & & $-0.0411^{*}$ & & \\
\hline & & & $(0.0235)$ & & \\
\hline \multirow[t]{2}{*}{$\mathrm{d} 1 \mathrm{~d} 2$} & & & & -0.0291 & \\
\hline & & & & $(0.0403)$ & \\
\hline \multirow[t]{2}{*}{$\mathrm{d} 1 \mathrm{~d} 2 \mathrm{~d} 3$} & & & & & -0.0430 \\
\hline & & & & & $(0.0332)$ \\
\hline \multirow[t]{2}{*}{ Constant } & $0.218^{* * *}$ & $0.230 * * *$ & $0.205 * * *$ & $0.212 * * *$ & $0.204^{* *}$ \\
\hline & $(0.0578)$ & $(0.0607)$ & $(0.0641)$ & $(0.0759)$ & $(0.0777)$ \\
\hline Observations & 72 & 72 & 67 & 66 & 63 \\
\hline R-squared & 0.473 & 0.478 & 0.523 & 0.501 & 0.506 \\
\hline
\end{tabular}

Robust standard errors in parentheses $* * * p<0.01,{ }^{* *} p<0.05, * p<0.1$ 
Table 9: Regression results of split samples-The Impact of CBI on Inflation with low D1

\begin{tabular}{|c|c|c|c|c|c|}
\hline & WITHOUT D & WITH D ALL & WITH D1 & WITH D1D2 & WITH D1D2D3 \\
\hline VARIABLES & inflation & inflation & inflation & inflation & inflation \\
\hline \multirow[t]{2}{*}{ cbi full } & $-0.0730 *$ & -0.0670 & -0.0715 & -0.0724 & -0.0805 \\
\hline & $(0.0417)$ & $(0.0455)$ & $(0.0444)$ & $(0.0456)$ & $(0.0513)$ \\
\hline \multirow[t]{2}{*}{ gdppc 2002} & -0.00748 & -0.00361 & -0.00508 & -0.00740 & -0.00266 \\
\hline & $(0.0101)$ & $(0.0101)$ & $(0.00917)$ & $(0.0101)$ & $(0.0122)$ \\
\hline \multirow[t]{2}{*}{$\mathrm{mu}$} & $-0.0424 * *$ & $-0.0536 * *$ & $-0.0562 * *$ & $-0.0435^{*}$ & $-0.0479 *$ \\
\hline & $(0.0189)$ & $(0.0241)$ & $(0.0205)$ & $(0.0253)$ & $(0.0246)$ \\
\hline \multirow[t]{2}{*}{ umi } & 0.0347 & 0.0385 & 0.0313 & 0.0344 & 0.0336 \\
\hline & $(0.0272)$ & $(0.0305)$ & $(0.0258)$ & $(0.0267)$ & $(0.0301)$ \\
\hline \multirow[t]{2}{*}{ oildy } & -0.0229 & -0.0301 & -0.0231 & -0.0232 & -0.0317 \\
\hline & $(0.0160)$ & $(0.0186)$ & $(0.0164)$ & $(0.0161)$ & $(0.0184)$ \\
\hline \multirow[t]{2}{*}{ ped 2002} & 0.00499 & 0.00552 & 0.00707 & 0.00484 & -0.000103 \\
\hline & $(0.0202)$ & $(0.0193)$ & $(0.0181)$ & $(0.0210)$ & $(0.0216)$ \\
\hline \multirow[t]{2}{*}{ growth } & -0.0327 & 0.00526 & 0.0127 & -0.0328 & -0.0299 \\
\hline & $(0.202)$ & $(0.208)$ & $(0.228)$ & $(0.208)$ & $(0.196)$ \\
\hline \multirow[t]{2}{*}{ trade } & $0.600 * * *$ & $0.622 * * *$ & $0.572 * * *$ & $0.599 * * *$ & $0.623 * * *$ \\
\hline & $(0.172)$ & $(0.181)$ & $(0.162)$ & $(0.179)$ & $(0.176)$ \\
\hline \multirow[t]{2}{*}{ d_all } & & -0.0836 & & & \\
\hline & & $(0.0777)$ & & & \\
\hline \multirow[t]{2}{*}{$\mathrm{d} 1$} & & & -0.0807 & & \\
\hline & & & $(0.0529)$ & & \\
\hline \multirow[t]{2}{*}{$\mathrm{d} 1 \mathrm{~d} 2$} & & & & -0.00624 & \\
\hline & & & & $(0.0826)$ & \\
\hline \multirow[t]{2}{*}{$\mathrm{d} 1 \mathrm{~d} 2 \mathrm{~d} 3$} & & & & & -0.0707 \\
\hline & & & & & $(0.0803)$ \\
\hline \multirow[t]{2}{*}{ Constant } & $0.165^{* *}$ & $0.206^{* *}$ & $0.211 * *$ & 0.170 & $0.204^{* *}$ \\
\hline & $(0.0778)$ & $(0.0873)$ & $(0.0762)$ & $(0.112)$ & $(0.0958)$ \\
\hline Observations & 32 & 32 & 32 & 32 & 30 \\
\hline R-squared & 0.694 & 0.712 & 0.716 & 0.694 & 0.723 \\
\hline
\end{tabular}

Robust standard errors in parentheses; $* * * p<0.01, * * p<0.05, * p<0.1$ 
Table 10: Regression results of split samples-The Impact of CBI on Inflation with High D1

\begin{tabular}{||l|l|l|l|l|l||}
\hline & WITHOUT_D & WITH_D_ALL & WITH_D1 & WITH_D1D2 & WITH_D1D2D3 \\
\hline VARIABLES & inflation & inflation & inflation & inflation & inflation \\
\hline cbi_full & -0.0459 & -0.0458 & -0.0462 & -0.0421 & -0.0455 \\
\hline & $(0.0374)$ & $(0.0385)$ & $(0.0367)$ & $(0.0396)$ & $(0.0385)$ \\
\hline gdppc_2002 & -0.0241 & -0.0237 & -0.0238 & -0.0221 & -0.0196 \\
\hline & $(0.0153)$ & $(0.0158)$ & $(0.0161)$ & $(0.0153)$ & $(0.0151)$ \\
\hline mu & $-0.0556^{* * *}$ & $-0.0559^{* * *}$ & $-0.0556^{* * *}$ & $-0.0487^{* * *}$ & $-0.0485^{* * *}$ \\
\hline & $(0.0156)$ & $(0.0162)$ & $(0.0158)$ & $(0.0160)$ & $(0.0153)$ \\
\hline umi & $0.0383^{*}$ & 0.0392 & 0.0386 & 0.0203 & 0.0315 \\
\hline & $(0.0219)$ & $(0.0234)$ & $(0.0240)$ & $(0.0235)$ & $(0.0238)$ \\
\hline oildy & 0.0192 & 0.0186 & 0.0186 & $0.0319^{* *}$ & 0.0235 \\
\hline & $(0.0128)$ & $(0.0140)$ & $(0.0185)$ & $(0.0140)$ & $(0.0140)$ \\
\hline ped_2002 & 0.00892 & 0.0103 & 0.00939 & 0.0126 & 0.00995 \\
\hline & $(0.0223)$ & $(0.0230)$ & $(0.0240)$ & $(0.0217)$ & $(0.0228)$ \\
\hline growth & $0.637^{*}$ & $0.613 *$ & $0.630^{*}$ & $0.761^{* *}$ & $0.666^{* *}$ \\
\hline & $(0.324)$ & $(0.338)$ & $(0.366)$ & $(0.294)$ & $(0.318)$ \\
\hline trade & -0.0348 & -0.0326 & -0.0329 & -0.109 & -0.0602 \\
\hline & $(0.0680)$ & $(0.0698)$ & $(0.0818)$ & $(0.0774)$ & $(0.0755)$ \\
\hline d_all & & -0.0119 & & & \\
\hline & & $(0.0569)$ & & & \\
\hline d1 & & & -0.00254 & & \\
\hline & & & $(0.0449)$ & & \\
\hline d1d2 & & & & 0.0841 & $(0.0590)$ \\
\hline & $0.235^{*}$ & $0.245^{*}$ & $0.236^{*}$ & 0.118 & \\
\hline d1d2d3 & $(0.117)$ & $(0.127)$ & $(0.120)$ & $(0.132)$ & $(0.123)$ \\
\hline & 35 & 35 & 35 & 34 & 33 \\
\hline Constant & 0.481 & 0.482 & 0.481 & 0.542 & 0.490 \\
\hline Observations & & & &
\end{tabular}

Robust standard errors in parentheses; ${ }^{* * *} p<0.01,{ }^{* *} p<0.05,{ }^{*} p<0.1$ 
Table 11: Regression results of Doorstep and the Impact of BI

\begin{tabular}{|c|c|c|c|c|c|}
\hline & $\begin{array}{l}\text { WITHOUT } \\
\text { D }\end{array}$ & WITH D_ALL & $\overline{\text { WITH D1 }}$ & WITH D1D2 & 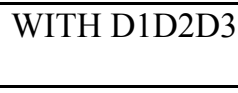 \\
\hline VARIABLES & ped & ped & ped & ped & ped \\
\hline \multirow[t]{2}{*}{ ped_2002 } & $0.490 * * *$ & $0.514^{* * *}$ & $0.495 * * *$ & $0.510 * * *$ & $0.514 * * *$ \\
\hline & $(0.0652)$ & $(0.0563)$ & $(0.0589)$ & $(0.0631)$ & $(0.0787)$ \\
\hline \multirow[t]{2}{*}{ growth } & 0.355 & 0.327 & 0.141 & 0.265 & 0.287 \\
\hline & $(0.454)$ & $(0.412)$ & $(0.431)$ & $(0.465)$ & $(0.456)$ \\
\hline \multirow[t]{2}{*}{ trade } & -0.326 & -0.231 & -0.319 & -0.464 & -0.397 \\
\hline & $(0.393)$ & $(0.353)$ & $(0.365)$ & $(0.334)$ & $(0.342)$ \\
\hline \multirow[t]{2}{*}{ gdppc_2002 } & $-0.0253^{*}$ & $1.12 \mathrm{e}-05$ & 0.000438 & -0.00770 & -0.00254 \\
\hline & $(0.0129)$ & $(0.0171)$ & $(0.0156)$ & $(0.0164)$ & $(0.0198)$ \\
\hline \multirow[t]{2}{*}{ hipc } & -0.0412 & -0.0103 & -0.00946 & -0.0221 & -0.0164 \\
\hline & $(0.0395)$ & $(0.0405)$ & $(0.0346)$ & $(0.0381)$ & $(0.0439)$ \\
\hline \multirow[t]{2}{*}{ oil } & $-0.110^{* *}$ & $-0.129 * * *$ & $-0.137 * * *$ & $-0.136^{* *}$ & $-0.115^{* *}$ \\
\hline & $(0.0409)$ & $(0.0440)$ & $(0.0442)$ & $(0.0507)$ & $(0.0488)$ \\
\hline \multirow[t]{2}{*}{ budget_stage } & $-0.0605 * *$ & $-0.0534 * *$ & -0.00343 & -0.0273 & -0.0327 \\
\hline & $(0.0246)$ & $(0.0230)$ & $(0.0322)$ & $(0.0330)$ & $(0.0317)$ \\
\hline \multirow[t]{2}{*}{ d_all } & & $-0.226^{* *}$ & & & \\
\hline & & $(0.0965)$ & & & \\
\hline \multirow[t]{2}{*}{$\mathrm{d} 1$} & & & $-0.229 * * *$ & & \\
\hline & & & $(0.0654)$ & & \\
\hline \multirow[t]{2}{*}{$\mathrm{d} 1 \mathrm{~d} 2$} & & & & $-0.280 * * *$ & \\
\hline & & & & $(0.0912)$ & \\
\hline \multirow[t]{2}{*}{$\mathrm{d} 1 \mathrm{~d} 2 \mathrm{~d} 3$} & & & & & $-0.203^{*}$ \\
\hline & & & & & $(0.103)$ \\
\hline \multirow[t]{2}{*}{ Constant } & $0.421 * * *$ & $0.420 * * *$ & $0.335 * * *$ & $0.487 * * *$ & $0.373^{*}$ \\
\hline & $(0.119)$ & $(0.116)$ & $(0.116)$ & $(0.115)$ & $(0.186)$ \\
\hline Observations & 51 & 51 & 47 & 46 & 43 \\
\hline R-squared & 0.863 & 0.879 & 0.867 & 0.879 & 0.863 \\
\hline
\end{tabular}

Robust standard errors in parentheses $* * * p<0.01,{ }^{*} p<0.05, * p<0$. 
Table 12: Regression results when interacting Doorsteps and Budget Index

\begin{tabular}{|c|c|c|c|c|}
\hline & "D_ALL*BUDGET & D1*BUDGET & $\begin{array}{l}\text { D1D2*BUDGET } \\
\end{array}$ & " D1D2D3*BUDGET \\
\hline VARIABLES & ped & Ped & ped & ped \\
\hline \multirow[t]{2}{*}{ ped_2002 } & $0.516^{* * *}$ & $0.500^{* * *}$ & $0.521^{* * *}$ & $0.514^{* * *}$ \\
\hline & $(0.0540)$ & $(0.0551)$ & $(0.0613)$ & $(0.0761)$ \\
\hline \multirow[t]{2}{*}{ growth } & 0.450 & 0.551 & 0.597 & 0.488 \\
\hline & $(0.447)$ & $(0.445)$ & $(0.464)$ & $(0.496)$ \\
\hline \multirow[t]{2}{*}{ trade } & -0.245 & -0.332 & -0.518 & -0.395 \\
\hline & $(0.363)$ & $(0.357)$ & $(0.346)$ & $(0.346)$ \\
\hline \multirow{2}{*}{ gdppc 2002} & 0.000440 & -0.00236 & -0.00684 & -0.00661 \\
\hline & $(0.0178)$ & $(0.0160)$ & $(0.0172)$ & $(0.0213)$ \\
\hline \multirow[t]{2}{*}{ hipc } & -0.00954 & -0.0118 & -0.0249 & -0.0215 \\
\hline & $(0.0413)$ & $(0.0362)$ & $(0.0393)$ & $(0.0440)$ \\
\hline \multirow[t]{2}{*}{ oil } & $-0.133 * * *$ & $-0.147 * * *$ & $-0.142 * *$ & $-0.126^{* *}$ \\
\hline & $\begin{array}{l}(0.0459) \\
\end{array}$ & $(0.0471)$ & $(0.0534)$ & $(0.0547)$ \\
\hline \multirow[t]{2}{*}{ budget stage } & -0.286 & $-0.263^{* * *}$ & $-0.367^{* * *}$ & -0.399 \\
\hline & $(0.206)$ & $(0.116)$ & $(0.142)$ & $(0.246)$ \\
\hline \multirow[t]{2}{*}{ d_all } & -0.667 & & & \\
\hline & $(0.399)$ & & & \\
\hline \multirow[t]{2}{*}{ dbudget } & 0.228 & & & \\
\hline & $(0.201)$ & & & \\
\hline \multirow[t]{2}{*}{$\mathrm{d} 1$} & & $-0.676^{* * *}$ & & \\
\hline & & $(0.197)$ & & \\
\hline \multirow{2}{*}{ d1budget } & & $0.243 * *$ & & \\
\hline & & $(0.100)$ & & \\
\hline \multirow[t]{2}{*}{ d1d2 } & & & $-0.905 * * *$ & \\
\hline & & & $(0.271)$ & \\
\hline \multirow[t]{2}{*}{ d1d2budget } & & & $0.329^{* *}$ & \\
\hline & & & $(0.134)$ & \\
\hline \multirow[t]{2}{*}{$\mathrm{d} 1 \mathrm{~d} 2 \mathrm{~d} 3$} & & & & $-0.869^{*}$ \\
\hline & & & & $(0.467)$ \\
\hline \multirow[t]{2}{*}{ d1d2d3budget } & & & & 0.351 \\
\hline & & & & $(0.234)$ \\
\hline \multirow[t]{2}{*}{ Constant } & $0.856^{* *}$ & $0.801 * * *$ & $1.094 * * *$ & $1.087^{* *}$ \\
\hline & $(0.408)$ & $(0.218)$ & $(0.277)$ & $(0.528)$ \\
\hline Observations & 51 & 47 & 46 & 43 \\
\hline R-squared & 0.881 & 0.878 & 0.887 & 0.869 \\
\hline
\end{tabular}

Robust standard errors in parentheses $* * * p<0.01,{ }^{* *} p<0.05, * p<0.1$ 
Table 13: Regression results of split samples-The Impact of BI on PED with Low D1

\begin{tabular}{|c|c|c|c|c|c|}
\hline & WITHOUT D & "WITH D ALL & WITH D1 & WITH D1D2 & WITH D1D2D3 \\
\hline VARIABLES & ped & Ped & ped & ped & ped \\
\hline \multirow{2}{*}{ ped_2002 } & $0.707 * * *$ & $0.707 * * *$ & $0.699 * * *$ & $0.710 * * *$ & $0.756 * * *$ \\
\hline & $(0.0420)$ & $(0.0499)$ & $(0.0326)$ & $(0.0327)$ & $(0.0840)$ \\
\hline \multirow[t]{2}{*}{ growth } & -0.458 & -0.460 & -0.368 & -0.376 & -0.207 \\
\hline & $(0.321)$ & $(0.331)$ & $(0.226)$ & $(0.290)$ & $(0.426)$ \\
\hline \multirow[t]{2}{*}{ trade } & $0.804 * *$ & 0.792 & $0.847 * *$ & $0.825^{*}$ & 0.658 \\
\hline & $(0.353)$ & $(0.484)$ & $(0.350)$ & $(0.402)$ & $(0.492)$ \\
\hline \multirow[t]{2}{*}{ gdppc 2002} & $-0.0361 * *$ & -0.0368 & $-0.0285^{* *}$ & $-0.0296^{* *}$ & -0.00641 \\
\hline & $(0.0127)$ & $(0.0253)$ & $(0.0109)$ & $(0.0136)$ & $(0.0360)$ \\
\hline \multirow[t]{2}{*}{ hipc } & $-0.137 * * *$ & $-0.138 * * *$ & $-0.129 * * *$ & $-0.133 * * *$ & $-0.119 * * *$ \\
\hline & $(0.0241)$ & $(0.0235)$ & $(0.0158)$ & $(0.0180)$ & $(0.0270)$ \\
\hline \multirow[t]{2}{*}{ oildy } & $-0.0900 * *$ & $-0.0891^{*}$ & $-0.102 * * *$ & $-0.107 * *$ & $-0.0947 * *$ \\
\hline & $(0.0301)$ & $(0.0423)$ & $(0.0294)$ & $(0.0430)$ & $(0.0420)$ \\
\hline \multirow[t]{2}{*}{ budget_stage } & $-0.0791 * * *$ & $-0.0792 * * *$ & -0.0521 & $-0.0739 * * *$ & $-0.0745^{* *}$ \\
\hline & $(0.0208)$ & $(0.0216)$ & $(0.0305)$ & $(0.0213)$ & $(0.0244)$ \\
\hline \multirow[t]{2}{*}{ d_all } & & 0.00607 & & & \\
\hline & & $(0.151)$ & & & \\
\hline \multirow[t]{2}{*}{$\mathrm{d} 1$} & & & -0.162 & & \\
\hline & & & $(0.0931)$ & & \\
\hline \multirow[t]{2}{*}{$\mathrm{d} 1 \mathrm{~d} 2$} & & & & -0.128 & \\
\hline & & & & $(0.138)$ & \\
\hline \multirow[t]{2}{*}{$\mathrm{d} 1 \mathrm{~d} 2 \mathrm{~d} 3$} & & & & & -0.0301 \\
\hline & & & & & $(0.161)$ \\
\hline \multirow[t]{2}{*}{ Constant } & $0.496 * * *$ & $0.497 * * *$ & $0.517 * * *$ & $0.548 * * *$ & 0.241 \\
\hline & $(0.102)$ & $(0.109)$ & $(0.0892)$ & $(0.113)$ & $(0.226)$ \\
\hline Observations & 21 & 21 & 21 & 21 & 19 \\
\hline R-squared & 0.974 & 0.974 & 0.980 & 0.977 & 0.975 \\
\hline
\end{tabular}

Robust standard errors in parentheses; ${ }^{* * *} p<0.01,{ }^{* *} p<0.05, * p<0.1$ 
Table 14: Regression results of split samples-The Impact of BI on PED with High D1

\begin{tabular}{|c|c|c|c|c|c|}
\hline & WITHOUT_D & WITH_D_ALL & WITH_D1 & WITH_D1D2 & WITH_D1D2D3 \\
\hline VARIABLES & ped & Ped & ped & ped & ped \\
\hline \multirow{2}{*}{ ped_2002 } & $0.446^{* * *}$ & $0.488 * * *$ & $0.470 * * *$ & $0.499 * * *$ & $0.497 * * *$ \\
\hline & $(0.104)$ & $(0.108)$ & $(0.102)$ & $(0.0869)$ & $(0.104)$ \\
\hline \multirow[t]{2}{*}{ growth } & 1.479 & 1.210 & 1.265 & 1.070 & 1.080 \\
\hline & $(1.501)$ & $(1.365)$ & $(1.521)$ & $(1.228)$ & $(1.246)$ \\
\hline \multirow[t]{2}{*}{ trade } & -0.377 & -0.357 & -0.335 & -0.816 & -0.827 \\
\hline & $(0.571)$ & $(0.473)$ & $(0.590)$ & $(0.498)$ & $(0.515)$ \\
\hline \multirow[t]{2}{*}{ gdppc 2002} & -0.0244 & -0.00751 & -0.00636 & -0.0277 & -0.0291 \\
\hline & $(0.0258)$ & $(0.0334)$ & $(0.0320)$ & $(0.0348)$ & $(0.0359)$ \\
\hline \multirow[t]{2}{*}{ hipc } & -0.0237 & -0.0182 & -0.0158 & -0.0384 & -0.0400 \\
\hline & $(0.0519)$ & $(0.0543)$ & $(0.0556)$ & $(0.0583)$ & $(0.0597)$ \\
\hline \multirow[t]{2}{*}{ oildy } & -0.208 & -0.249 & -0.234 & -0.200 & -0.196 \\
\hline & $(0.160)$ & $(0.176)$ & $(0.166)$ & $(0.153)$ & $(0.177)$ \\
\hline \multirow[t]{2}{*}{ budget_stage } & 0.00178 & -0.0143 & 0.00106 & 0.0226 & 0.0222 \\
\hline & $(0.0545)$ & $(0.0549)$ & $(0.0560)$ & $(0.0610)$ & $(0.0665)$ \\
\hline \multirow[t]{2}{*}{ d_all } & & -0.275 & & & \\
\hline & & $(0.235)$ & & & \\
\hline \multirow[t]{2}{*}{$\mathrm{d} 1$} & & & -0.129 & & \\
\hline & & & $(0.103)$ & & \\
\hline \multirow[t]{2}{*}{$\mathrm{d} 1 \mathrm{~d} 2$} & & & & -0.0296 & \\
\hline & & & & $(0.102)$ & \\
\hline \multirow[t]{2}{*}{$\mathrm{d} 1 \mathrm{~d} 2 \mathrm{~d} 3$} & & & & & -0.0265 \\
\hline & & & & & $(0.179)$ \\
\hline \multirow[t]{2}{*}{ Constant } & 0.211 & 0.406 & 0.217 & 0.215 & 0.223 \\
\hline & $(0.231)$ & $(0.279)$ & $(0.239)$ & $(0.221)$ & $(0.255)$ \\
\hline Observations & 26 & 26 & 26 & 25 & 24 \\
\hline R-squared & 0.844 & 0.862 & 0.849 & 0.908 & 0.901 \\
\hline
\end{tabular}

Robust standard errors in parentheses; $* * * p<0.01,{ }^{* *} p<0.05, * p<0.1$ 


\section{Appendix I: Databases Used for the Construction of the Doorsteps Index}

\begin{tabular}{|c|c|}
\hline NAME OF DATABASE & DESCRIPTION OF DATABASE \\
\hline Institutional Profiles Database (IPD) & $\begin{array}{l}\text { A database on the institutional characteristics of } \\
\text { developed and developing countries compiled by } \\
\text { Meisel, Aoudia et al. We use both the } 2006 \text { and the } \\
2009 \text { version of this database. The } 2006 \text { version } \\
\text { contains information on } 85 \text { countries, whereas the } \\
2009 \text { version contains information on } 123 \text { countries. } \\
\text { Note that several of the variables of the } 2006 \\
\text { database are not included in the } 2009 \text { database. We } \\
\text { always used the most recent available information. }\end{array}$ \\
\hline Polity IV & $\begin{array}{l}\text { A dataset compiled by Marshall and Jaggers. It } \\
\text { contains information on political regime } \\
\text { characteristics and transitions covering "all major, } \\
\text { independent states in the global system (i.e. states } \\
\text { with total populations of } 500,000 \text { or more in the } \\
\text { most recent year; currently } 163 \text { countries) over the } \\
\text { period between } 1800 \text { and } 2008 \text { ". Unless otherwise } \\
\text { indicated, we use data for } 2008 .\end{array}$ \\
\hline Economic Freedom of the World (EFW) & $\begin{array}{l}\text { A database developed for the Economic Freedom } \\
\text { Network and compiled by Gwartney, Lawson et al. } \\
\text { The current (2009) version contains information on } \\
\text { economic freedom in } 141 \text { nations between } 1979 \text { and } \\
2007 \text {. Unless otherwise indicated, we use data for } \\
2007 \text {. }\end{array}$ \\
\hline Database of Political Institutions (DPI) & $\begin{array}{l}\text { This dataset is published by the World Bank and has } \\
\text { been compiled by Keefer, Clarke, Walsh, and Groff. } \\
\text { The most recent version (2008) contains data on } \\
\text { political institutions in } 178 \text { countries between } 1975 \\
\text { until } 2006 \text {. Unless otherwise indicated, we used data } \\
\text { from } 2006 \text {. }\end{array}$ \\
\hline IISS Armed Conflict Database (ACD) & $\begin{array}{l}\text { This dataset is published by the International } \\
\text { Institute for Strategic Studies contains current } \\
\text { information on armed conflicts worldwide. We used } \\
\text { the most recent available information (mostly 2009) } \\
\text { for the construction of our variables. }\end{array}$ \\
\hline
\end{tabular}

${ }^{33}$ www.systemicpeace.org/polity/polity4.htm. 
Appendix II: Arnone (2007) CBI Index Scores Updated for 2009

\begin{tabular}{|c|c|c|c|c|}
\hline COUNTRY & GROUP & POLITICAL AUTONOMY & ECONOMIC AUTONOMY & OVERALL \\
\hline Albania & LMI & 0.75 & 0.75 & 0.75 \\
\hline Algeria & UMI & 1.00 & 0.63 & 0.81 \\
\hline Angola & LMI & 0.25 & 0.38 & 0.31 \\
\hline Argentina & UMI & 0.88 & 0.75 & 0.81 \\
\hline Armenia & LMI & 0.63 & 0.75 & 0.69 \\
\hline Azerbaijan & LMI & 0.50 & 0.63 & 0.56 \\
\hline Bangladesh & LI & 0.00 & 0.38 & 0.19 \\
\hline Benin & LI & 0.50 & 0.88 & 0.69 \\
\hline Bolivia & LMI & 0.50 & 1.00 & 0.75 \\
\hline Botswana & UMI & 0.13 & 0.75 & 0.44 \\
\hline Brazil & UMI & 0.25 & 0.63 & 0.44 \\
\hline Burkina Faso & LI & 0.50 & 0.88 & 0.69 \\
\hline Burundi & LI & 0.38 & 0.75 & 0.56 \\
\hline Cameroon & LMI & 0.63 & 0.88 & 0.75 \\
\hline CAR & LI & 0.63 & 0.88 & 0.75 \\
\hline Chad & LI & 0.63 & 0.88 & 0.75 \\
\hline Chile & UMI & 0.38 & 0.88 & 0.63 \\
\hline Colombia & UMI & 0.25 & 0.75 & 0.50 \\
\hline Congo, Rep. & LMI & 0.63 & 0.88 & 0.75 \\
\hline Congo, DR & LI & 0.38 & 0.75 & 0.56 \\
\hline Costa Rica & UMI & 0.50 & 0.88 & 0.69 \\
\hline Cote d'Ivoire & LI & 0.50 & 0.88 & 0.69 \\
\hline Dominican Rep. & UMI & 0.25 & 0.88 & 0.56 \\
\hline Egypt & LMI & 0.13 & 0.38 & 0.25 \\
\hline El Salvador & LMI & 0.63 & 1.00 & 0.81 \\
\hline Ethiopia & LI & 0.38 & 0.63 & 0.50 \\
\hline Macedonia & UMI & 1.00 & 0.75 & 0.88 \\
\hline Gabon & UMI & 0.63 & 0.88 & 0.75 \\
\hline Georgia & LMI & 0.75 & 1.00 & 0.88 \\
\hline Ghana & LI & 0.38 & 0.63 & 0.50 \\
\hline Haiti & LI & 0.50 & 0.50 & 0.50 \\
\hline Honduras & LMI & 0.25 & 0.88 & 0.56 \\
\hline Indonesia & LMI & 0.50 & 0.75 & 0.63 \\
\hline Jamaica & UMI & 0.13 & 0.50 & 0.31 \\
\hline Jordan & LMI & 0.25 & 0.50 & 0.38 \\
\hline Kazakhstan & UMI & 0.50 & 0.88 & 0.69 \\
\hline Kenya & LI & 0.25 & 0.63 & 0.44 \\
\hline Kyrgyz, Rep. & LI & 1.00 & 0.75 & 0.88 \\
\hline Mali & LI & 0.50 & 0.88 & 0.69 \\
\hline Mauritius & UMI & 0.25 & 0.50 & 0.38 \\
\hline Mexico & UMI & 0.75 & 0.88 & 0.81 \\
\hline Moldova & LMI & 0.75 & 0.75 & 0.75 \\
\hline Mozambique & LI & 0.38 & 0.50 & 0.44 \\
\hline Namibia & UMI & 0.25 & 0.50 & 0.38 \\
\hline Nepal & LI & 0.50 & 0.63 & 0.56 \\
\hline Pakistan & LMI & 0.50 & 0.63 & 0.56 \\
\hline Paraguay & LMI & 0.25 & 0.75 & 0.50 \\
\hline Peru & UMI & 0.38 & 1.00 & 0.69 \\
\hline Philippines & LMI & 0.63 & 0.63 & 0.63 \\
\hline Poland & UMI & 1.00 & 0.88 & 0.94 \\
\hline
\end{tabular}

CInternational Monetary Fund. Not for Redistribution 
55

\begin{tabular}{||l|l|l|l|l||}
\hline Romania & UMI & 1.00 & 0.63 & 0.81 \\
\hline Russia & UMI & 0.38 & 0.50 & 0.44 \\
\hline Senegal & LI & 0.50 & 0.88 & 0.69 \\
\hline Serbia & UMI & 0.75 & 0.63 & 0.69 \\
\hline South Africa & UMI & 0.25 & 0.38 & 0.31 \\
\hline Sudan & LMI & 0.13 & 0.63 & 0.38 \\
\hline Tanzania & LI & 0.38 & 0.63 & 0.50 \\
\hline Thailand & LMI & 0.38 & 0.38 & 0.38 \\
\hline Togo & LI & 0.50 & 0.88 & 0.69 \\
\hline Tunisia & LMI & 0.63 & 0.88 & 0.75 \\
\hline Turkey & UMI & 0.63 & 1.00 & 0.81 \\
\hline Uganda & LI & 0.63 & 0.63 & 0.63 \\
\hline Ukraine & LMI & 0.75 & 0.75 & 0.75 \\
\hline Uruguay & UMI & 0.63 & 0.63 & 0.63 \\
\hline Venezuela & UMI & 0.63 & 0.75 & 0.69 \\
\hline Yemen & LI & 0.38 & 0.50 & 0.44 \\
\hline Zambia & LI & 0.50 & 0.50 & 0.50 \\
\hline Zimbabwe & LI & 0.13 & 0.63 & 0.38 \\
\hline
\end{tabular}




\section{6}

\section{Appendix III: Dabla Norris et al. (2010) BI Index Scores}

\begin{tabular}{|l|l|l||}
\hline COUNTRY & GROUP & BUDGET INDEX \\
\hline Albania & LMI & 2.13 \\
\hline Armenia & LMI & 2.79 \\
\hline Azerbaijan & LMI & 2.20 \\
\hline Benin & LI & 2.02 \\
\hline Botswana & UMI & 2.05 \\
\hline Burkina Faso & LI & 2.21 \\
\hline Cameroon & LMI & 1.21 \\
\hline Chad & LI & 1.92 \\
\hline Colombia & UMI & 3.03 \\
\hline Costa Rica & UMI & 2.20 \\
\hline Cote d'Ivoire & LI & 1.58 \\
\hline Dominican Republic & UMI & 1.36 \\
\hline Ecuador & LMI & 1.56 \\
\hline Egypt & LMI & 2.12 \\
\hline Ethiopia & LI & 1.89 \\
\hline Macedonia & UMI & 2.51 \\
\hline Georgia & LMI & 2.57 \\
\hline Ghana & LI & 2.23 \\
\hline Honduras & LMI & 1.44 \\
\hline Indonesia & LMI & 2.40 \\
\hline Jordan & LMI & 2.74 \\
\hline Kazakhstan & UMI & 2.06 \\
\hline Kenya & LI & 1.88 \\
\hline Kyrgyz Republic & LI & 1.61 \\
\hline Madagascar & LI & 2.42 \\
\hline Malawi & LI & 1.76 \\
\hline Mali & LI & 2.30 \\
\hline Mauritius & UMI & 1.84 \\
\hline Mexico & UMI & 2.94 \\
\hline Moldova & LMI & 2.94 \\
\hline Morocco & LMI & 2.32 \\
\hline Mozambique & LI & 2.27 \\
\hline Namibia & UMI & 2.17 \\
\hline Nepal & LI & 1.82 \\
\hline Niger & LI & 1.76 \\
\hline Pakistan & LMI & 1.96 \\
\hline Paraguay & LMI & 1.87 \\
\hline Peru & UMI & 3.13 \\
\hline Philippines & LMI & 1.75 \\
\hline Russia & UMI & 2.45 \\
\hline Senegal & LI & 1.80 \\
\hline Serbia & UMI & 2.27 \\
\hline South Africa & UMI & 2.47 \\
\hline Sudan & LMI & 0.55 \\
\hline Tanzania & LI & 2.59 \\
\hline Thailand & LMI & 2.33 \\
\hline Togo & LI & 1.28 \\
\hline Turkey & UMI & 2.22 \\
\hline Uganda & LI & 2.43 \\
\hline Ukraine & LMI & 1.91 \\
\hline Yemen & LI & 1.95 \\
\hline Zambia & LI & 1.79 \\
\hline & & \\
\hline & & \\
\hline
\end{tabular}




\section{Appendix IV: Description of Variables}

\section{Variable}

Budget_Stage

CBI

CGPB

D_All

D1

D2

D3

D1D2

D1D2D3

Dlbudget

D1D2budget

D1D2D3budget

Democracy

Fractionalization
Source

Dabla-Norris et al. (2010)

Arnone et al. (2007)

Updated version of Arnone

IMF WEO 2009

Own index

Own index

Own index

Own index

Own index

Own index

Own index

Own index

Own index

Polity IV 2009

Alesina et al. (2002)

\section{Description}

Budget Stage Index

Arnone CBI Index updated using latest $\mathrm{CB}$ legislation

Average central government primary balance as ratio of GDP between 2003 and 2007

Average of all available (at least two) doorstep indices

Doorstep 1 index (aggregated with equal weights)

Doorstep 2 index (aggregated with equal weights)

Doorstep 3 index (aggregated with equal weights)

Average of D1 and D2

Average of D1, D2, and D3

Product of and D1 and Budget

And Dabla-Norris et al. (2010) Stage Index

Product of and D1D2 and and Dabla-Norris et al. (2010) Stage Index

Product of and D1D2D3 and Budget and Dabla-Norris et al. (2010)

Stage Index

Average of institutionalized

Democracy between 2003 and 2007; scaled to range between 0 and 1

Average Index of fractionalization in ethnicity, language and religion Note: old data (especially for ethnicity); but this should not have changed too much 


\section{Appendix IV: Description of Variables (continued)}

\begin{tabular}{|c|c|c|}
\hline Variable & Source & Description \\
\hline GDPPC & World Bank WDI 2009 & $\begin{array}{l}\text { Ln of average GDP per capita in } \\
\text { PPP terms (constant } 2005 \\
\text { international dollar) between } 2003 \\
\text { and } 2007\end{array}$ \\
\hline GDPPC_2002 & World Bank WDI 2009 & $\begin{array}{l}\text { Ln of GDP per capita in } \\
\text { PPP terms (constant } 2005 \\
\text { international dollar) in } 2002\end{array}$ \\
\hline Growth & IMF WEO 2009 & $\begin{array}{l}\text { Average of annual GDP (constant } \\
\text { prices) growth between } 2003 \text { and } \\
2007\end{array}$ \\
\hline HIPC & IMF & $\begin{array}{l}\text { Dummy for completion of HIPC } \\
\text { until } 2007\end{array}$ \\
\hline MU & IMF & $\begin{array}{l}\text { Dummy for membership in a } \\
\text { monetary union }\end{array}$ \\
\hline Oil & IMF WEO 2009 & Dummy for oil-exporting countries \\
\hline PED & $\begin{array}{l}\text { World Bank WDI } 2009 \\
\text { IMF }\end{array}$ & $\begin{array}{l}\text { Average public external debt as } \\
\text { ratio of GDP between } 2003 \text { and } \\
2007\end{array}$ \\
\hline PED_2002 & $\begin{array}{l}\text { World Bank WDI } 2009 \\
\text { IMF }\end{array}$ & $\begin{array}{l}\text { Average public external debt as } \\
\text { ratio of GDP in } 2002\end{array}$ \\
\hline PRGF & IMF $\quad$ MONA 2009 & $\begin{array}{l}\text { Dummy for poverty reduction } \\
\text { and growth facility between } 2000 \\
\text { and } 2007\end{array}$ \\
\hline Revenue & World Bank WDI 2009 & $\begin{array}{l}\text { Average central government total } \\
\text { revenue incl. grants as ratio of GDP } \\
\text { between } 2003 \text { and } 2007\end{array}$ \\
\hline
\end{tabular}

